\title{
FILTERING, FEEDING, AND DIGESTION IN THE LAMELLIBRANCH LASAEA RUBRA
}

\author{
By Dorothy Ballantine \\ The Plymouth Laboratory \\ and J. E. Morton \\ Department of Zoology, Queen Mary College, University of London
}

(Text-figs. I-II)

Lasaea rubra is the smallest and commonest of Plymouth bivalves. It is intertidal on rocky shores, often in immense numbers, in crevices and other protected places, and in Pygmaea pumila (Colman, 1940). This bivalve is an excellent laboratory animal. It remains fully active for several days under laboratory conditions, and a large number of animals can be used in a single experiment, eliminating the variations in activity found when dealing with a few, or single specimens of larger animals. Because of the relatively high position Lasaea rubra may occupy on the shore its feeding cycle is broken by regular dry periods at each tide. Thus, for experiments relating to periodicity in feeding, we have an animal whose times of feeding can easily be ascertained and experimentally varied over a wide range. Lastly, in making serial sections and in examining total gut contents, in work on the digestive system, the small size of the animal is of obvious advantage.

The present paper is devoted to an account of filtering rates with various food organisms, variations in filtering activity and the relation of filtering to feeding and digestion. Further work has been completed by one of us (J.E.M.) on the mechanism of digestion and the cycle of activity of the digestive gland, and experiments are in progress on respiration during submersion and exposure.

We record our special thanks to Dr Mary Parke, botanist at the Plymouth Laboratory, for making available the unialgal cultures of the organisms used, and for her invariable kindness and sound advice. One of us (J.E.M.) has been the holder of a University of London Table at the Plymouth Laboratory, and both of us are grateful to the Director and staff of the Laboratory for many kindnesses. In particular, Dr H. W. Harvey, F.R.S., allowed us the frequent use of his absorptiometer, and gave us great encouragement throughout the work, while Dr B. C. Abbott gave valued assistance in discussion and evaluation of results. 


\section{Methods}

Specimens of Lasaea rubra were collected on the day of each experiment from the limestone rocks below the Hoe bathing pool, in front of the Plymouth Laboratory. To ensure the sampling of a constant population, collections were made, except where otherwise stated, from as nearly as possible the same group of crevices on an outcrop of rocks $18 \mathrm{in}$. to $2 \mathrm{ft}$. below the upper limit of Chthamalus stellatus. The animals were used as soon as possible after collection. In experiments on filtering rates a group of twenty animals was selected for each experiment and placed in cultures of micro-organisms, in optical glass cuvettes supplied by the Tintometer Co. Ltd., Salisbury. Six such vessels were used in sets of replicate experiments, each containing $3.5 \mathrm{ml}$., with an optical depth of $20 \mathrm{~mm}$. The unialgal cultures employed as food were grown in Erdschreiber (enriched sea water) medium, and it was found that Lasaea rapidly resume normal behaviour in this medium, aggregating in a cluster at the bottom of the cuvette and attaching to each other by byssus threads, with foot and siphon extended (Fig. I). At this stage normal filtering activity was assumed to have begun. With practice in selection, the eye could pick out samples of Lasaea rubra conforming closely to a standard size distribution (Fig. 2A).

Filtering rates were determined by the measurement of the optical density of the medium by means of a Harvey absorptiometer, constructed as described by Harvey (1948). The chief modifications introduced were those outlined by Spencer (1954) for use with micro-organisms. After a series of densitydilution comparisons (see Fig. 2B) the concentration of organisms was taken to be directly proportional to log optical density. Experiments were continued for periods of 6-8 h, and readings of the optical density of the cultures were taken at intervals. An adaptation period of the first hour was allowed, and the rate of filtration was then calculated from the first to the fourth hours. In the experiments using Arenicola haemoglobin, measurements were made on the Unicam spectrophotometer.

In experiments where filtering, feeding and digestion were compared it was not possible to allow the animals to adapt themselves to experimental conditions for the first hour. In these experiments measurements were made of the amount of Phaeodactylum tricornutum filtered, the amount extruded as pseudofaeces, the amount ingested and the amount digested. In order to do this four experiments were set up and one was discontinued every half hour. After the period of filtration, optical density was measured in order to calculate the quantity of Phaeodactylum filtered, $3 \mathrm{ml}$. of the supernatant culture was then removed, and the remaining $0.5 \mathrm{ml}$. containing the pseudofaeces was then brought up to the original volume by the addition of $3 \mathrm{ml}$. of filtered sea water. A second reading of optical density was then made, which-after correction for the $0.5 \mathrm{ml}$. of supernatant culture left-gave the quantity of 
Phaeodactylum in the pseudofaeces. In each experiment the difference between the amount filtered and the amount recovered as pseudofaeces was taken to represent the fraction removed by ingestion. This difference was found in practice to be too small to measure accurately by the absorptiometric method. Gut contents were therefore measured directly by the quick dissection of two

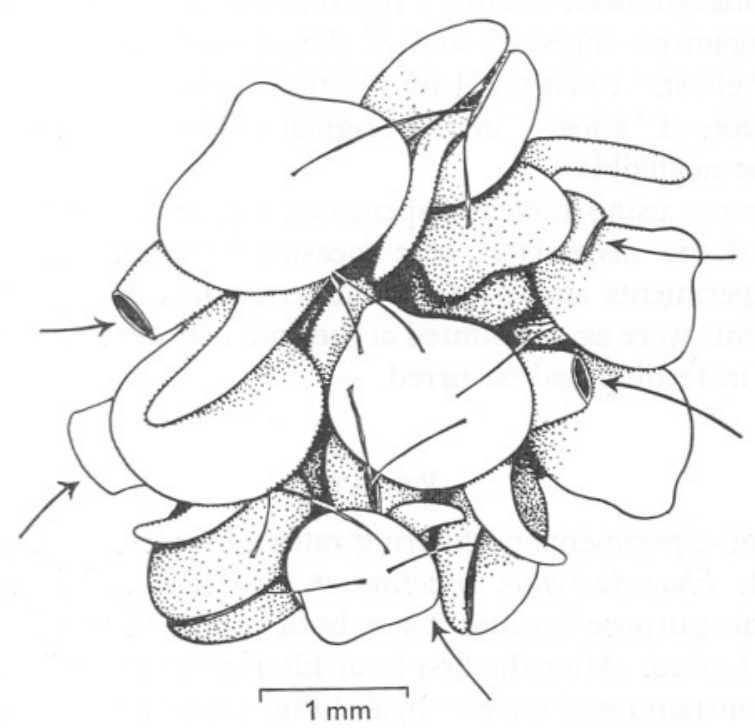

Fig. I. A group of Lasaea rubra, attached together by byssus threads in the normal manner. The inhalant siphon and the foot are extended, and the arrows show the directions of inhalant water currents.
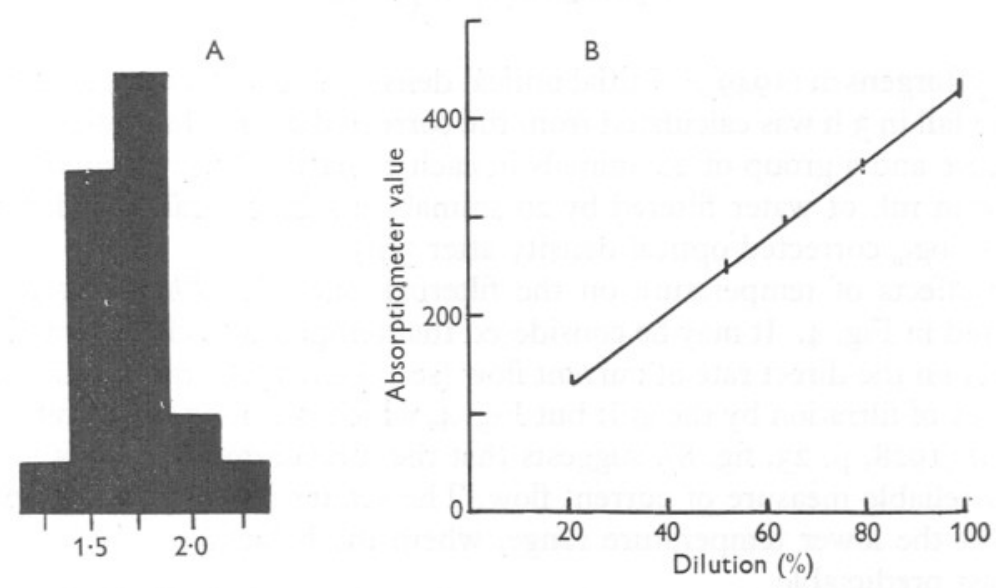

Fig. 2. A: size distribution in mm of a typical group of 20 Lasaea rubra, selected in experiments on filtering rates. $\mathrm{B}$ : the relation between dilutions of a culture of Phaeodactylum tricornutum and the scale of optical density on the Harvey absorptiometer. 
animals from each cuvette, on dry slides under a binocular microscope. The full stomach, and as much of the intestine as contained faeces was isolated and opened, so that the total contents were shed upon the slide. Remains of tissue were as far as possible removed and the total gut contents taken up in $0.2 \mathrm{ml}$. of filtered sea water. The concentration of Phaeodactylum cells was then estimated by haemacytometer counts, a measure being thus obtained of the total number of organisms ingested, and of the proportion of intact, undigested cells, and of 'ghosts' constituted by the thin walls of empty, digested cells. (The proportion of 'ghosts' in the original culture was found for present purposes to be negligible.)

In experiments using mixed suspensions the proportions of the various constituents of the suspension were measured by haemacytometer counts before the experiments and either the supernatant culture, pseudofaeces or stomach contents were again counted at the end, in order to determine whether any selection in feeding had occurred.

\section{RESULTS}

In the series of experiments on filtering rates a large number of results were obtained with Phaeodactylum tricornutum (Table I). Phaeodactylum was selected for this purpose because it was both readily available in culture and acceptable to Lasaea. After the first hour filtering was usually continued at a more or less constant rate for 6 or $7 \mathrm{~h}$, and Fig. 3 shows curves for a typical set of six experiments. Filtering rates were calculated from optical density by applying the formula

$$
P_{t}=P_{0} \exp \left[-\frac{m}{M} t\right]
$$

used by Jørgensen (1949). ${ }^{1}$ Initial optical density at I h was corrected to 500, and the fall in $3 \mathrm{~h}$ was calculated from the corrected $4 \mathrm{~h}$ reading, using $3.5 \mathrm{ml}$. of culture and a group of 20 animals in each cuvette. Thus, $m$, equalling the volume in ml. of water filtered by 20 animals in I h, was calculated as 2.684 $\left(2.699-\log _{10}\right.$ corrected optical density after $\left.3 \mathrm{~h}\right)$.

The effects of temperature on the filtering rate with Phaeodactylum are expressed in Fig. 4. It may be considered that temperature changes will exert an effect on the direct rate of current flow (see Gray, I928) rather than on the efficiency of filtration by the gill; but Fig. 4, which is closely comparable with Galtsoff (I928, p. 23, fig. 8), suggests that the measurement of filtration rate gives a reliable measure of current flow. The scatter is widest in the experiments at the lower temperature range, where the behaviour of the bivalves was least predictable.

${ }^{1} M=$ quantity of water in cuvette; $m=$ quantity of water filtered; $P_{t}$ and $P_{0}$ are the concentrations of suspended material at times $t$ and $o$ respectively. 


\section{Table I. Filtering Rates of LAsaEA RUbRA with PhaEodactylum TRICORNUTUM}

(Each value represents the volume filtered in $\mathrm{ml}$./ $\mathrm{h}$, over $3 \mathrm{~h}$ by 20 animals, at room temperature.)

Set of experiments

I

2

3

$4 \quad 0.364,0.308,0.419$

$5 \quad 0.406,0.536,0.399$

$6 \quad 0.4744,0.9212,0.809, \mathrm{I} .435,0.628,0.847$

$7 \quad 0.795,0.754,0.524,0.577, \mathrm{I} .469,0.8 \mathrm{I} 79$

$8 \quad 0.3672,0.6396,0.9162$

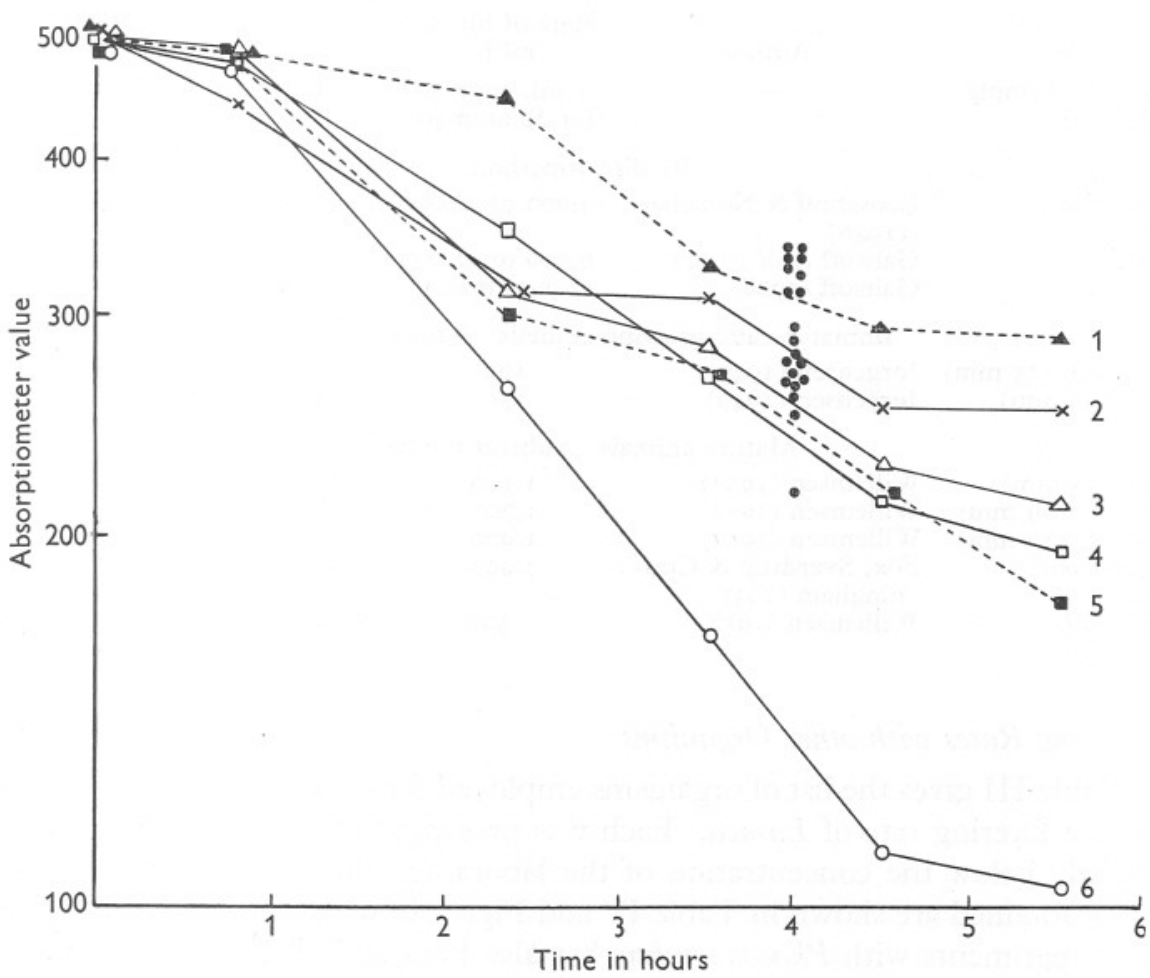

Fig. 3. Six curves showing the filtering rates of sets of 20 Lasaea rubra in Phaeodactylum, in a typical series of experiments over $5 \frac{1}{2} \mathrm{~h}$. It is suggested that the highest rate (Expt. 6) approaches the value likely to be achieved by continuous filtering by all the animals during the whole experimental period. The scatter points show the end values of optical density in a further series of twenty experiments, all values being determined with reference to an initial base line of 500 absorptiometer units. 


\section{Comparison with other Lamellibranchs}

A pumping rate of $\mathrm{I} \mathrm{ml} . / \mathrm{h} / 20$ animals at $I 5^{\circ} \mathrm{C}$ is cited in Table II for Lasaea rubra as being typical of the higher rates obtained with groups of mainly adult animals, sampled as in Fig. 2 A. Table II summarizes the information on the filtering rates for other lamellibranchs. Verwey (I952, pp. I93-4) gives a useful review of what has already been published on this subject. Filtering rates are produced by comparison of the volume of water filtered by one animal with the volume by displacement of the total animal with shell closed.

\section{Table II. Comparison of the Filtering Rate of LASAEA RUBRA WITH OTHER LAMELLIBRANCHS}

\begin{tabular}{|c|c|c|c|c|c|}
\hline $\begin{array}{c}\text { Species } \\
\text { Lasaea rubra (sample }\end{array}$ & Author & $\begin{array}{l}\text { Rate of filtering } \\
(\mathrm{ml} / \mathrm{h})\end{array}$ & $\begin{array}{l}\text { Estimated } \\
\text { mean volume } \\
\text { of single } \\
\text { animal } \\
\text { I.2 } \mathrm{mm}^{3}\end{array}$ & $\begin{array}{l}\text { Vol. water } \\
\text { filtered in } \\
\text { I h/volume } \\
\text { of animal }\end{array}$ & $\begin{array}{l}\text { Temp. } \\
\left({ }^{\circ} \mathrm{C}\right)\end{array}$ \\
\hline $\begin{array}{l}\text { Lasaea rubra (sample } \\
\text { as in Fig. } 2 \mathrm{~A} \text { ) }\end{array}$ & - & $\begin{array}{l}\text { I ml. approx. } \\
\text { (for } 20 \text { animals) }\end{array}$ & $\mathrm{I} \cdot 2 \mathrm{~mm}^{3}$ & 42 & \\
\hline \multicolumn{6}{|c|}{ By direct method } \\
\hline Ostrea virginica & $\begin{array}{l}\text { Loosanoff \& Nomejko } \\
\text { (1946) }\end{array}$ & I3,000 to 20,000 & $100 \mathrm{~cm}^{3}$ & I30-200 & - \\
\hline $\begin{array}{l}\text { O. virginica } \\
\text { O. virginica }\end{array}$ & $\begin{array}{l}\text { Galtsoff et al. (I947) } \\
\text { Galtsoff (I928) }\end{array}$ & $\begin{array}{l}\text { 6,000 to } 12,000 \\
\text { 3,900 (max.) }\end{array}$ & $\begin{array}{l}100 \mathrm{~cm}^{3} \\
100 \mathrm{~cm}^{3}\end{array}$ & $\begin{array}{c}60-120 \\
39\end{array}$ & - \\
\hline \multicolumn{6}{|c|}{ Immature and growing animals - indirect method } \\
\hline Mytilus edulis (15 mm) & Jørgensen (I949) & I6o & $0.8 \mathrm{~cm}^{3}$ & 200 & $17-20$ \\
\hline M. edulis (30 mm) & Jørgensen (I949) & 750 & $5 \mathrm{~cm}^{3}$ & I50 & $17-20$ \\
\hline \multicolumn{6}{|c|}{ Mature animals_-indirect method } \\
\hline M. edulis (48 mm) & Willemsen (1952) & I,IOO & I9 $\mathrm{cm}^{3}$ & 58 & I $2-15$ \\
\hline M. edulis $(67-69 \mathrm{~mm})$ & Willemsen (1952) & I,700 & $30 \mathrm{~cm}^{3}$ & 57 & $12-15$ \\
\hline M. edulis $(77-80 \mathrm{~mm})$ & Willemsen (I952) & I,900 & $40 \mathrm{~cm}^{3}$ & 47 & I2-I5 \\
\hline $\begin{array}{l}\text { M. californianus } \\
(74 \mathrm{~mm})\end{array}$ & $\begin{array}{l}\text { Fox, Sverdrup \& Cun- } \\
\text { ningham (I937) }\end{array}$ & $\mathrm{I}, 400$ & $38 \mathrm{~cm}^{3}$ & 35 & $20-23$ \\
\hline $\begin{array}{l}\text { Cardium edule } \\
(30-40 \mathrm{~mm})\end{array}$ & Willemsen (I952) & 500 & c. $23 \mathrm{~cm}^{3}$ & 22 & $\begin{array}{l}17 \cdot 3^{-} \\
19 \cdot 5\end{array}$ \\
\hline
\end{tabular}

\section{Filtering Rates with other Organisms}

Table III gives the list of organisms employed for comparative experiments on the filtering rate of Lasaea. Each was presented in unialgal culture at or slightly below the concentration of the laboratory culture, and the filtering rates obtained are shown in Table IV and Fig. 5, to which the range of values for experiments with Phaeodactylum has also been added for comparison.

As can be seen from Table IV a striking variation appeared in the filtering rates with various organisms, in particular with Gymnodinium veneficum, in which no sustained filtering is observed at all, and which has been shown to be toxic to fish, other molluscs (Ballantine, unpublished) and Hemimysis lamornae (Bainbridge, I953, p. 393, as Gymnodinium II). Experiments were 
therefore carried out on the effect of pre-treatment with $G$. veneficum on the subsequent filtering rate in Phaeodactylum. When placed in the toxic culture the Lasaea fail to aggregate or to put out the foot and siphon, but in spite of this shell-closure some of the toxin (which is present both in the cells and the

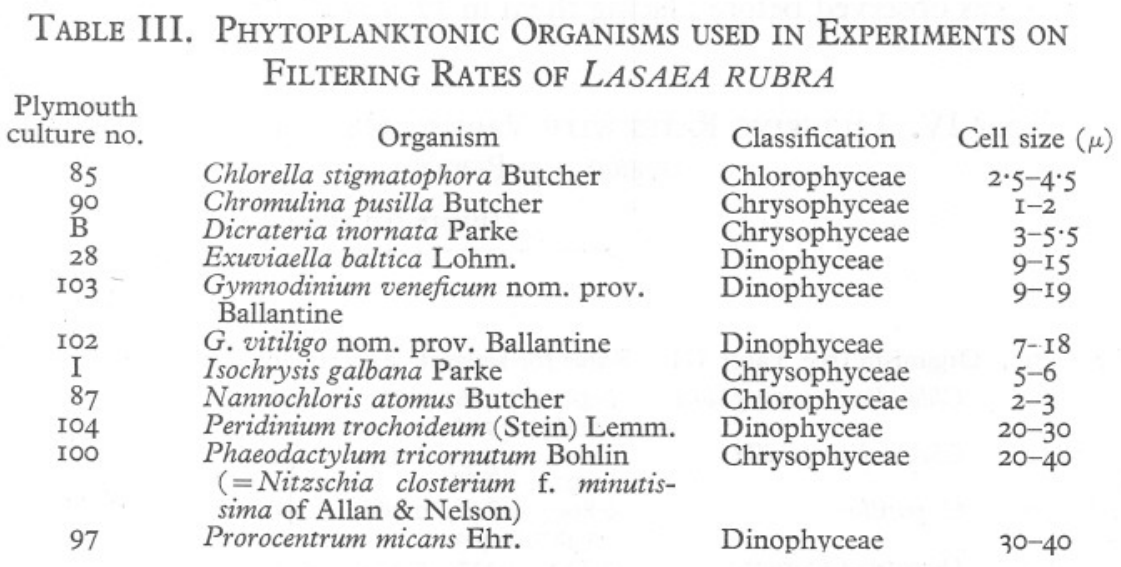

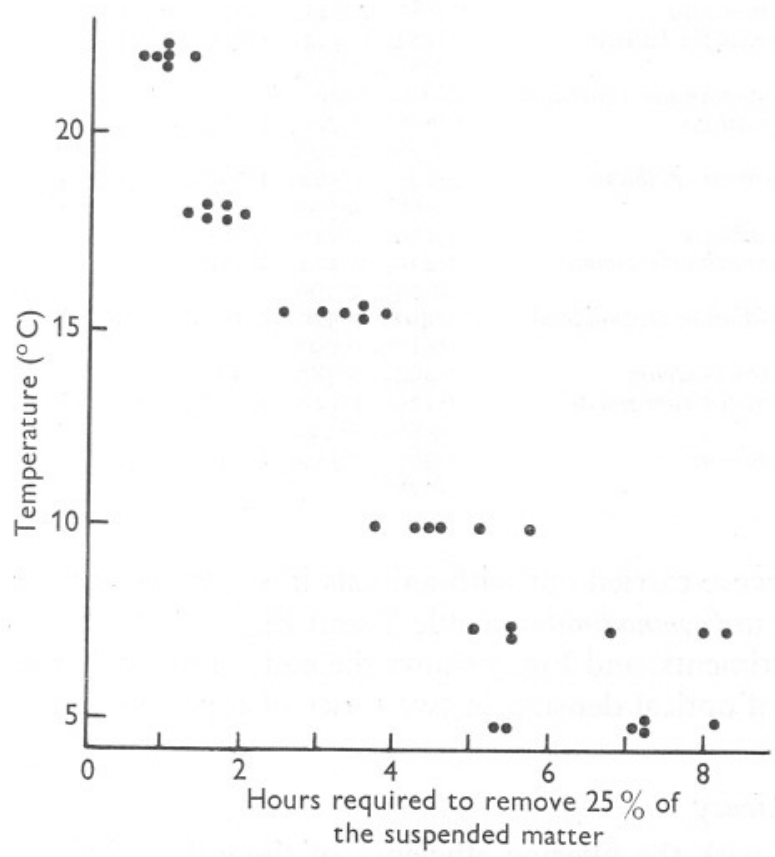

Fig. 4. The relation between filtering rate of Lasaea in Phaeodactylum and temperature. Filtering rate is expressed inversely as the time required (in hours) to remove $25 \%$ of the suspended food under the experimental conditions. (Cf. Galtsoff, 1928, fig. 8.) 
supernatant water) must enter the mantle cavity, and the extent of the retardation of subsequent filtering is roughly proportional to the duration of contact with the toxin (eventually nearly all animals appeared to recover). On removal from the toxic culture the experimental animals were washed for $30 \mathrm{~min}$ in several changes of filtered sea water, and full activity of foot and siphon was observed before placing them in Phaeodactylum culture. Control

\section{Table IV. Filtering Rates with Various Organisms Calculated OVER A 3 H PERIOD}

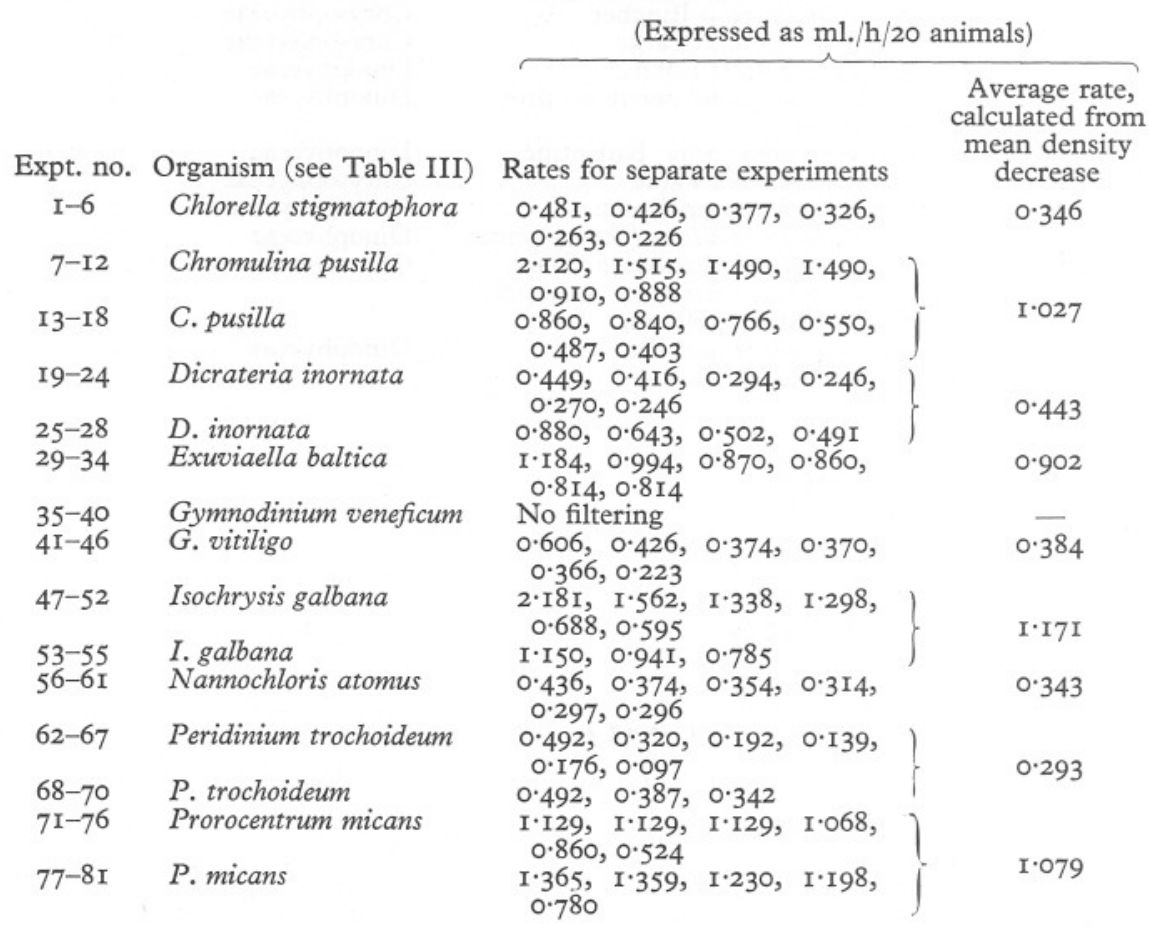

experiments were carried out with animals in sea water for a period equal to the exposure to Gymnodinium. Table V and Fig. 6 show the results obtained in these experiments, and Fig. 7 shows the end-points, referred to a base-line of 500 units of optical density, in two series of experiments and controls.

\section{Filtering Efficiency}

In dealing with the filtering efficiency of the gill, and the problem of the presence of a mucous sheet over the gill aiding in the retention of minute particles, several lines of approach were used. In sections of Lasaea rubra 
stained with Alcian blue (see Steedman, 1950), or with mucicarmine or azan, mucous glands could not be detected in the epithelium of the filaments. This evidence is admittedly open to the objection that the contents of glands actually present might have been discharged during feeding immediately prior to fixation, but even on the gills of animals fixed while actually

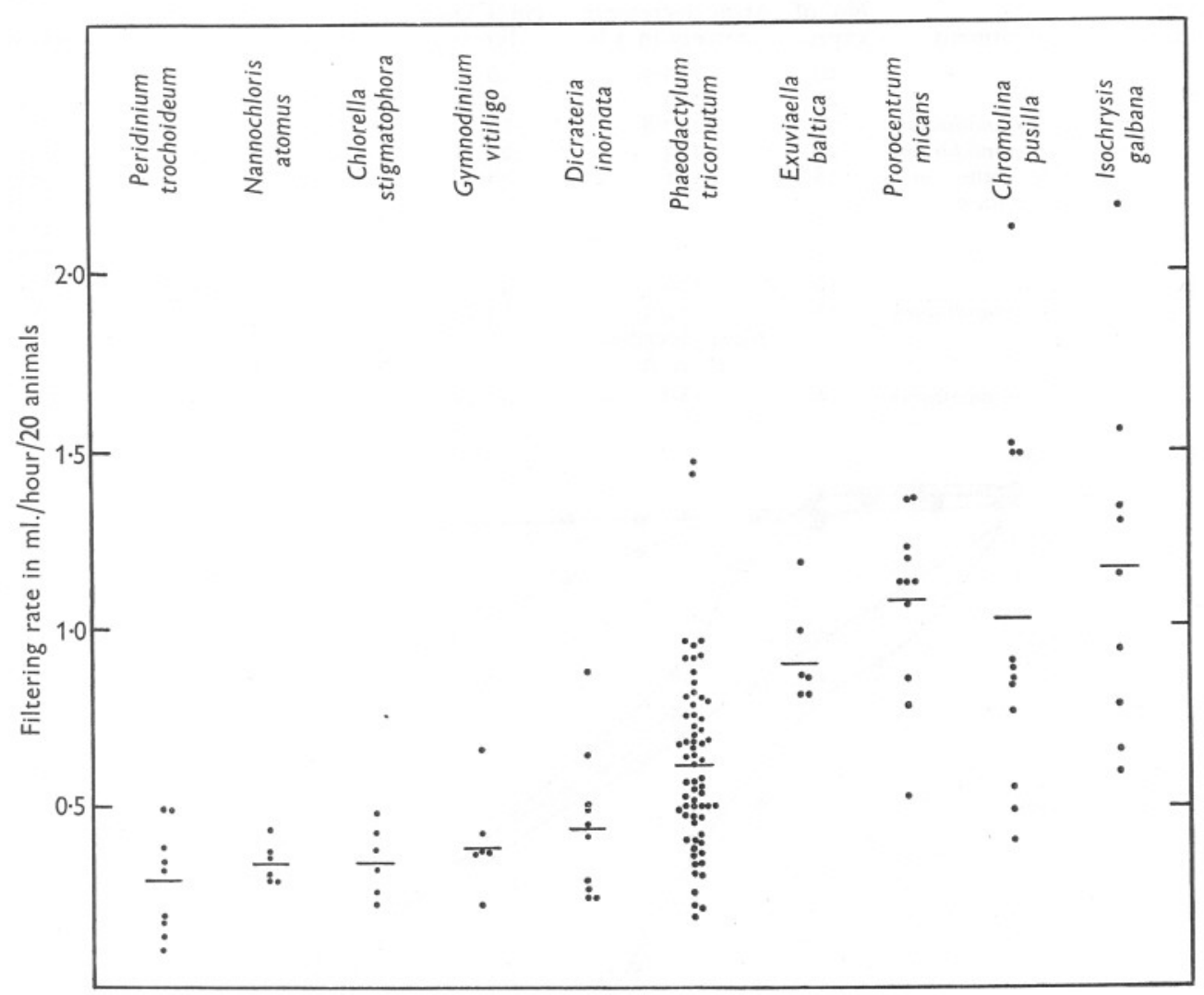

Fig. 5. The range of filtering rates exhibited by Lasaea rubra in all experiments with Phaeodactylum (Table I), and with the various organisms listed in Table III. The horizontal line on each range of values indicates the average filtering rate with that organism. Gymnodinium veneficum is omitted, as showing no measurable filtering rate in any experiment.

filtering 'Aquadag' no mucous covering could be detected by these staining methods.

Lasaea has also been shown to filter organisms and particles of size ranging from I to $50 \mu$ (i.e. from Chromulina pusilla, marine bacteria and 'Aquadag' to particles of 'Kieselguhr'). In general, the size of the organism, like the concentration of the suspension, appeared to have no correlatable effect on the 


\section{Table V. Effect of Pretreatment with GymnodiniUm Veneficum}

(Filtering rates of Lasaea rubra in Phaeodactylum tricornutum.)

Filtering rate ( $\mathrm{ml} . / \mathrm{h} / 20$ animals)

$\begin{array}{cl}\text { Group } & \\ \text { no. } & \text { Pre-treatment } \\ \text { I } & \text { None } \\ & \text { None } \\ & 5 \mathrm{~h} \text { in Gymnodinium } \\ & 5 \mathrm{~h} \text { in Gymnodinium } \\ & \text { Variable time in } \\ & \text { Gymnodinium }\end{array}$

2 None

$5 \mathrm{~h}$ in Gymnodinium

3 Io h in Gymnodinium
No. of Meandecreasein expts. density in $3 \mathrm{~h}$

$\begin{array}{lll}20 & 218.5 & \text { I6.02 } \\ 23 & 223 & 28 \cdot 11 \\ 20 & 147.8 & 15 \cdot 2 \\ 20 & 143 & 27.71 \\ 18 & \text { I5I } & 28.6\end{array}$

$\begin{array}{cc}\text { I9 } & \text { I69 } \\ \text { I8 } & 72 \cdot 3 \\ & \text { Mean decrease } \\ & \text { in ro h } \\ 6 & \text { I89 }\end{array}$

6

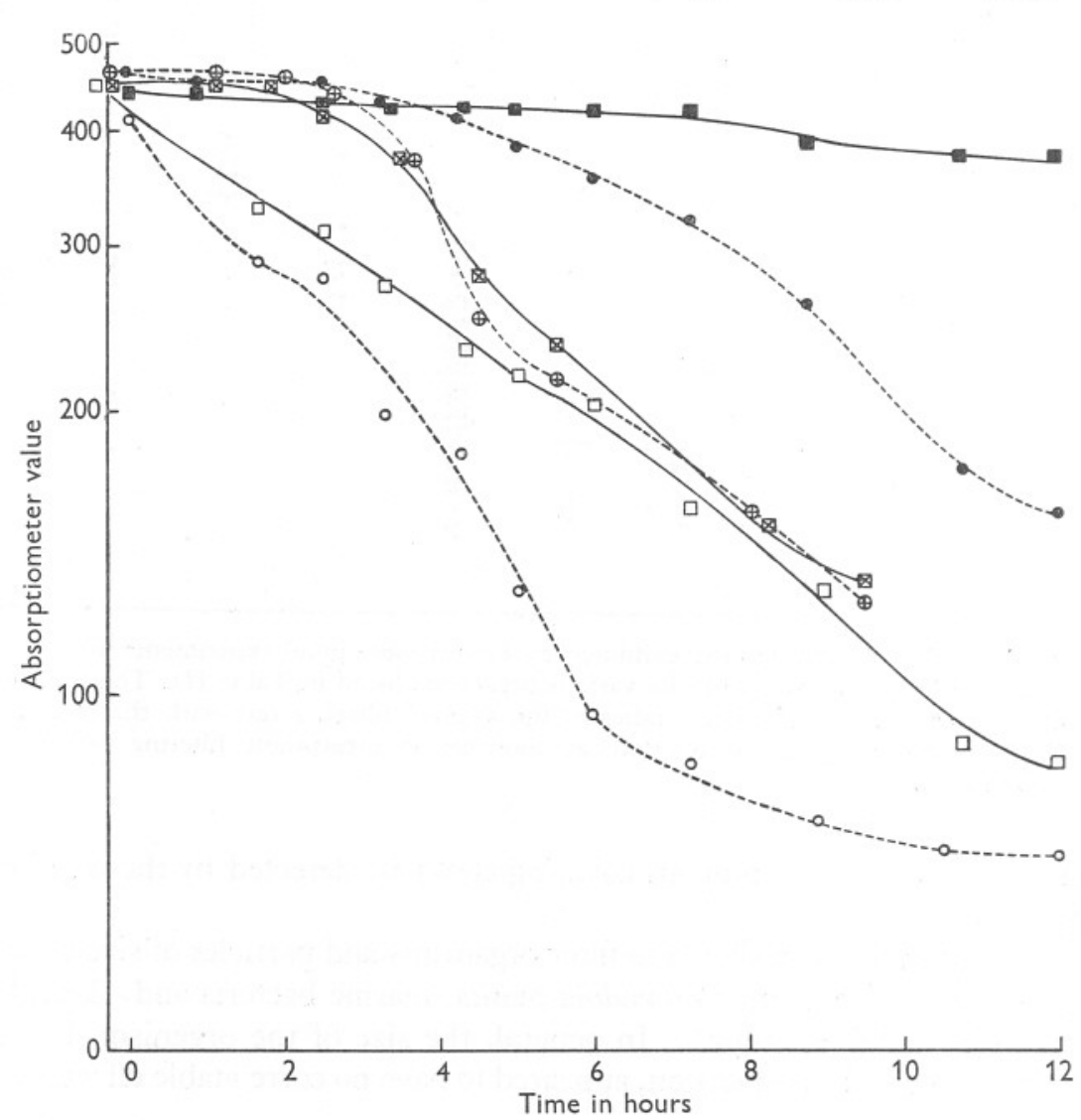

$\begin{array}{lllll}4 I .43 & 0.166 & 0.189 & 0.104\end{array}$

Filtering rate Extreme variations calculated from of filtering rate mean density

decrease Highest Lowest

$0.67 \quad 0.966 \quad 0.457$

$\begin{array}{lll}0.69 & 1.436 & 0.314\end{array}$

$0.41 \mathrm{II} \quad 0.644 \quad 0.243$

$0.396 \quad 0.937 \quad 0.113$

$0.42 \quad 0.92 I \quad 0.065$

$(2 \mathrm{~h}$ in (ro $\mathrm{h}$ in

Gymno- Gymno-

dinium) dinium)

$0.48 \quad 0.963 \quad 0.189$

$0.182 \quad 0.351 \quad 0.06$

Fig. 6. The effect of pretreatment with Gymnodinium veneficum on the subsequent filtering rate of Lasaea in Phaeodactylum. $\square-\square$ and $\bigcirc---\bigcirc$ are curves for control experiments; $\square-\square$ and $\oplus---\oplus$ for animals pretreated for $2 \mathrm{~h}$ in Gymnodinium; and - 
filtration. This would indicate a high degree of filtering efficiency of particles down to $\mathrm{I} \mu$ size.

With marine bacteria suspensions (Fig. 8) some filtration occurred in the first $20 \mathrm{~min}$, but later ceased, probably because of lack of oxygen, and the possible toxicity of the bacteria themselves.

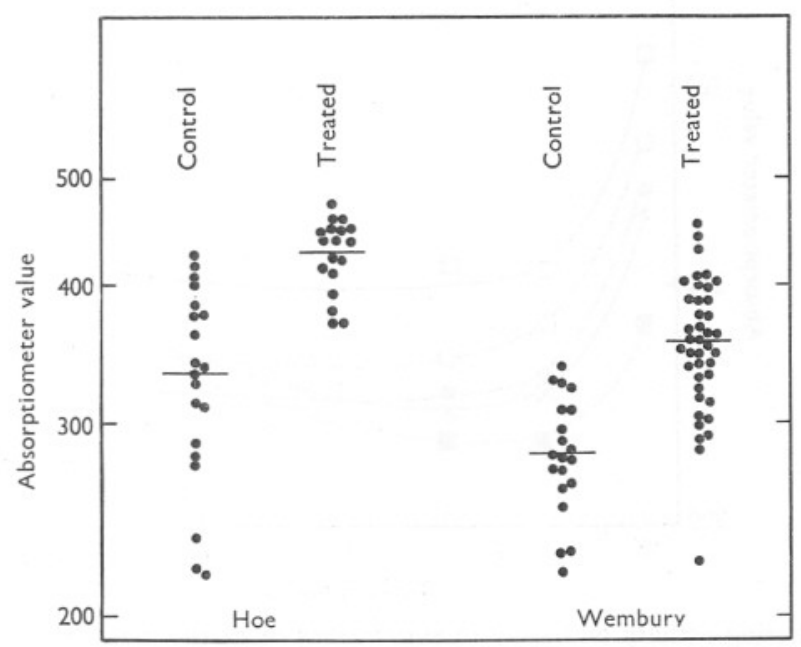

Fig. 7. The fall in optical density in $3 \mathrm{~h}$ of Phaeodactylum culture (from an initial base level of 500 absorptiometer units) in experiments using Lasaea rubra pretreated for $5 \mathrm{~h}$ with Gymnodinium veneficum, as compared with controls using Lasaea rubra from sea water. The horizontal line on each range is the average for that range. Two sets of experiments are recorded, and the higher level of the values obtained from Wembury is to be attributed to the use of animals larger than the average experimental size illustrated in Fig. 2A.

In addition to experiments using colloidal graphite ('Aquadag' ' $c$ ' and Graphite ' $s$ '), which gave rather variable results, work was carried out based on the results of Jørgensen \& Goldberg (1953) on the removal from suspensions, by the gill of Mytilus and Ostrea, of large protein molecules of vertebrate haemoglobin, and Haliotis and crab haemocyanin. The greatest retention $(25 \%)$ was obtained by Jørgensen \& Goldberg with crab haemocyanin, with less than $10 \%$ retention in the other experiments. It was suggested that filtration by, or adsorption on, a mucous sheet was responsible for the uptake of these large molecules. Parallel cases are the reports of the survival of clams for periods of several months in filtered beef-tea, and the known ability of lamellibranchs to live for long periods in particle-free solutions of organic nutrients. A series of experiments was carried out on Lasaea, using sets of 20 animals in $5 \mathrm{ml}$. of a solution of Arenicola marina haemoglobin in sea water (Table VI). It is perhaps necessary to point out that the percentages quoted 
in these results are not directly comparable with those of Jørgensen \& Goldberg, as experimental conditions varied in ways not ascertainable from the results as presented.

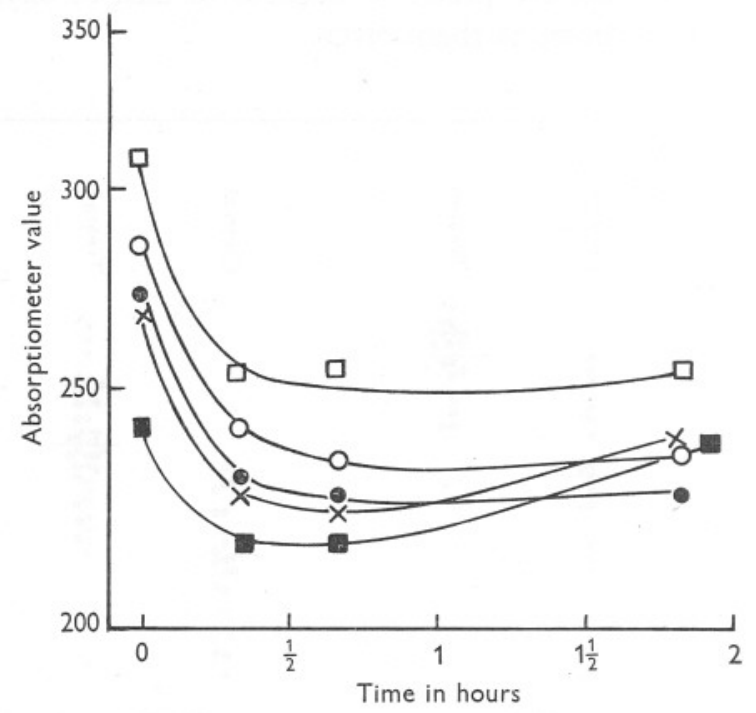

Fig. 8. The filtering activity of Lasaea in suspensions of marine bacteria. Filtering ceased after $40 \mathrm{~min}$, and the slight increase in optical density in some of the experiments after $2 \mathrm{~h}$ is probably to be attributed to bacterial division and the resuspension of bacteria from released pseudofaeces.

\section{Table VI. Removal of the Haemoglobin of the Blood of ARENICOLA MARINA, AFTER I2 H}

$\overbrace{\text { Ist }}^{\text {Readings at }} 4 \mathrm{I} 5 \mathrm{~m} \mu$ peak*

Expt. no.

I) 20 Lasaea used in

$3 \int$ each expt.

4.

5) Controls

6) (No animals)

$\begin{array}{ccc}\begin{array}{c}\text { Ist } \\ \text { reading }\end{array} & \begin{array}{c}\text { 2nd } \\ \text { reading }\end{array} & \% \text { fall } \\ \text { I350 } & \text { II50 } & \text { I5 } \\ \text { I350 } & \text { I150 } & \text { I5 } \\ \text { I350 } & \text { I275 } & 5.5 \\ \text { I350 } & \text { I275 } & 5.5 \\ \text { I350 } & \text { I350 } & - \\ \text { I350 } & \text { I360 } & -\end{array}$

Readings at $540 \mathrm{~m} \mu$ peak $\overbrace{\begin{array}{c}\text { Ist } \\ \text { reading }\end{array} \begin{array}{c}\text { 2nd } \\ \text { reading } \% \text { fall }\end{array}}$

- $\quad$ - $\quad$ -

2I0 $195 \quad 9 \cdot 3$

$210 \quad 180 \quad 8.6$

2I0 210 -

* A slight shift of peak between the first and second readings occurred both in experiments and controls, possibly due to oxidative changes.

\section{Filtering, Feeding and Digestion}

In experiments for the comparison of filtering, feeding and digestion rates (Tables VII and VIII), Lasaea rubra was found to ingest Phaeodactylum rapidly to the full capacity of the stomach. With the use of a thick suspension, the amount required to fill the gut is only a small fraction of the total filtered. 
The surplus of the filtered material is extruded from the pallial cavity as loosely compacted pseudofaeces. The results obtained using cultures of Phaeodactylum show that after $2 \mathrm{~h} 40 \%$ of the material within the stomach was digested, after continuous heavy feeding up to the time of examination. The results from Table XIV indicate that within a short time the total food ingested may be submitted to digestion.

Inspection of the curves for the four experiments shown (Fig. 9A) reveals that the rate of filtering continued to increase over the $2 \mathrm{~h}$ experimental period. Since, however, the curve for each of the four experiments closely agrees with the curve obtained by plotting the end-points of Expts. I-4, it is considered that this artificial curve gives an accurate picture of the conditions obtaining in any of the individual experiments. The larger value of the filtering rate towards the end of the experiments (Table VII), as compared with the values cited in Table I, may be ascribed to the greater number of large-sized Lasaea used in order to facilitate dissection of the gut. The shape of the curves,

\section{Table VII. Synopsis of Results in Experiment on Filtration and FEEDING IN LASAEA RUBRA}

\begin{tabular}{|c|c|c|c|c|}
\hline $\begin{array}{l}\text { Time } \\
\text { from start }\end{array}$ & $\begin{array}{c}\text { Filtering rate } \\
\text { (calculated from } \\
\text { fall in density } \\
\text { of supernatant) } \\
\text { (ml./h/ } \\
20 \text { animals) }\end{array}$ & $\begin{array}{l}\text { Total no. of } \\
\text { Phaeodactylum } \\
\text { filtered }\end{array}$ & $\begin{array}{c}\text { Total no. of } \\
\text { Phaeodactylum in } \\
\text { pseudofaeces (from } \\
\text { counts and } \\
\text { calibration curve) }\end{array}$ & $\begin{array}{c}\text { No. of } \\
\text { Phaeodactylum } \\
\text { in stomachs of } \\
20 \text { animals }\end{array}$ \\
\hline $\begin{array}{l}\frac{1}{2} \mathrm{~h} \\
\mathrm{I} \mathrm{h} \\
\mathrm{I} \frac{1}{2} \mathrm{~h} \\
2 \mathrm{~h}\end{array}$ & $\begin{array}{l}0.815 \\
I \cdot 100 \\
I \cdot 205 \\
I \cdot 825\end{array}$ & $\begin{array}{r}0.77 \times 10^{6} \\
2.99 \times 10^{6} \\
6.63 \times 10^{6} \\
13.39 \times 10^{6}\end{array}$ & $\begin{array}{l}0.7 \times 10^{6} \\
2.06 \times 10^{6} \\
3.67 \times 10^{6} \\
8.79 \times 10^{6}\end{array}$ & $\begin{array}{r}0.0725 \times 10^{6} \\
0.93 \times 10^{6} \\
2.90 \times 10^{6} \\
4.60 \times 10^{6}\end{array}$ \\
\hline
\end{tabular}

and the progressive increase in filtering rate, is probably due to the increased delay shown by these larger animals in acclimatizing themselves and resuming natural behaviour in the cuvettes. The total of digested cells can be seen to have risen steadily throughout the experiment (Fig. 9B), and the proportion of digested cells is probably rather greater than is apparent here, as some cells must have been completely digested, and have disappeared altogether. This number is not likely, however, to be large, as with experience even the faintest ' ghost' cells can be recognized, and the total time of the experiment was not sufficient for very extensive digestion. Fig. Io sums up the evidence from these experiments in a single diagram.

Most recent opinion agrees that any sorting that occurs on the gills or labial palps of lamellibranchs takes place by size and weight of particles, and that 'selection on other grounds, as according to organic or inorganic content, or according to digestibility or unpalatability is out of the question' (Verwey, I952). But since Fox (I936) earlier maintained that particles could be sorted according to their acceptability, and Loosanoff (1949) states that feeding Ostrea are capable of choosing between different flagellates, it was decided to 
Table ViII. Feeding and Digestion in a culture of PhaEodactylum

(Starting time of experiment I0.00 h, I8 August 1954.)

Total Phaeodactylum in stomach in thousands

\begin{tabular}{|c|c|c|c|c|c|c|c|c|c|c|}
\hline \multirow[b]{2}{*}{$\begin{array}{c}\text { Expt. } \\
\text { no. }\end{array}$} & \multirow[b]{2}{*}{ Time } & \multicolumn{3}{|c|}{ Animal I } & \multicolumn{3}{|c|}{${ }^{\text {Animal } 2}$} & \multicolumn{3}{|c|}{ Average } \\
\hline & & $\begin{array}{l}\text { Intact } \\
\text { cells }\end{array}$ & $\begin{array}{l}\text { Digested } \\
\text { 'ghosts' }\end{array}$ & Total & $\begin{array}{l}\text { Intact } \\
\text { cells }\end{array}$ & $\begin{array}{l}\text { Digested } \\
\text { 'ghosts' }\end{array}$ & Total & $\begin{array}{l}\text { Intact } \\
\text { cells }\end{array}$ & $\begin{array}{l}\text { Digested } \\
\text { 'ghosts' }\end{array}$ & Total \\
\hline I & 10.30 & 4 & - & 4 & 3 & 0.25 & 3.25 & 3.5 & 0.12 & 3.62 \\
\hline 2 & II $\cdot 00$ & 37 & 8 & 45 & 28 & IO & 38 & $32 \cdot 5$ & 9 & $4 \mathrm{I} \cdot 5$ \\
\hline 3 & II.3O & 82 & 40 & I22 & I34 & 40 & I74 & 108 & 40 & I 48 \\
\hline 4 & I2.00 & 102 & 80 & 182 & 172 & 106 & 278 & I37 & 93 & 230 \\
\hline $5^{\star}$ & 12.30 & I6 & $7 \cdot 5$ & 23.5 & 24 & 8 & 32 & 20 & $7 \cdot 75$ & $27 \cdot 75$ \\
\hline
\end{tabular}

* The rate of Expt. 5 was noticeably slower than that of the other 4 ; the values at $\mathrm{I} 2.30 \mathrm{~h}$ approximate most closely to those of Expt. 2 at II.00 h. These figures (Expt. 5) have not been expressed in the graphs in Fig. 9.

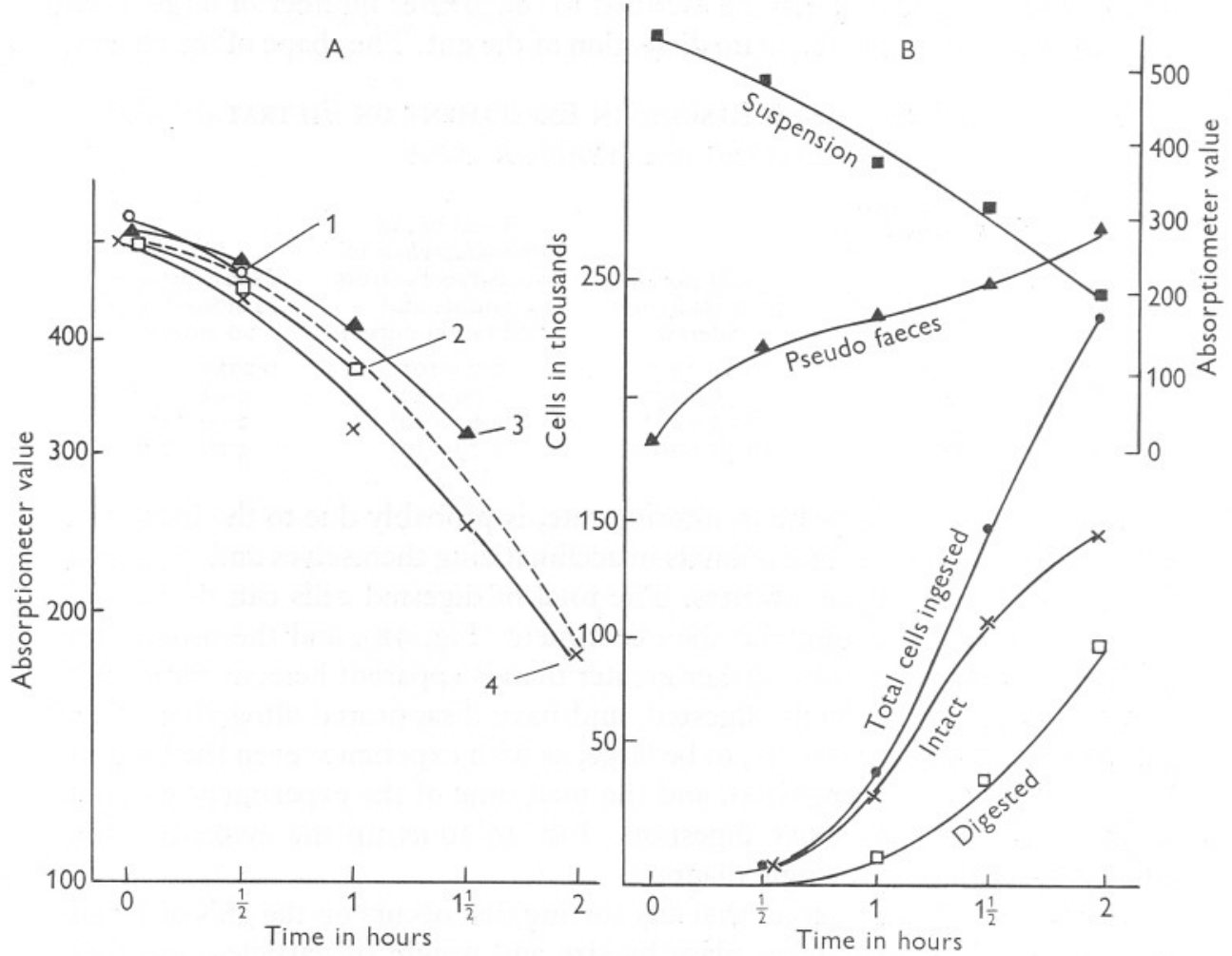

Fig. 9. A: the filtering rate of Lasaea in Phaeodactylum over $2 \mathrm{~h}$ in Expts. $\mathrm{I}-4$ referred to on p. 252. The broken line represents the hypothetical curve obtained by joining the points at which Expts. I-4 were discontinued. B: above-the optical density of the suspension of Phaeodactylum and of the resuspended pseudofaeces, over $2 \mathrm{~h}$, in the experiments referred to on p. 252; below-the numbers of cells (total, intact and digested) in the stomach of a single Lasaea at the same intervals (numbers estimated by haemacytometer counts). 
carry out some experiments on discrimination in Lasaea. It seemed likely that, in a small lamellibranch able to digest naked or thin-walled organisms better than diatoms and or armoured dinoflagellates, any sorting mechanisms available for rejecting large or unsuitable organisms would operate very effectively. Experiments were set up with the following mixtures, each cuvette containing 20 Lasaea: (a) Phaeodactylum tricornutum / Dicrateria inornata; (b) Peridinium trochoideum / Dicrateria; (c) Phaeodactylum / Chromulina pusilla; (d) Phaeodactylum / Thalassiosira fluviatilis; (e) Phaeodactylum / 'Kieselguhr' (diatomaceous earth).

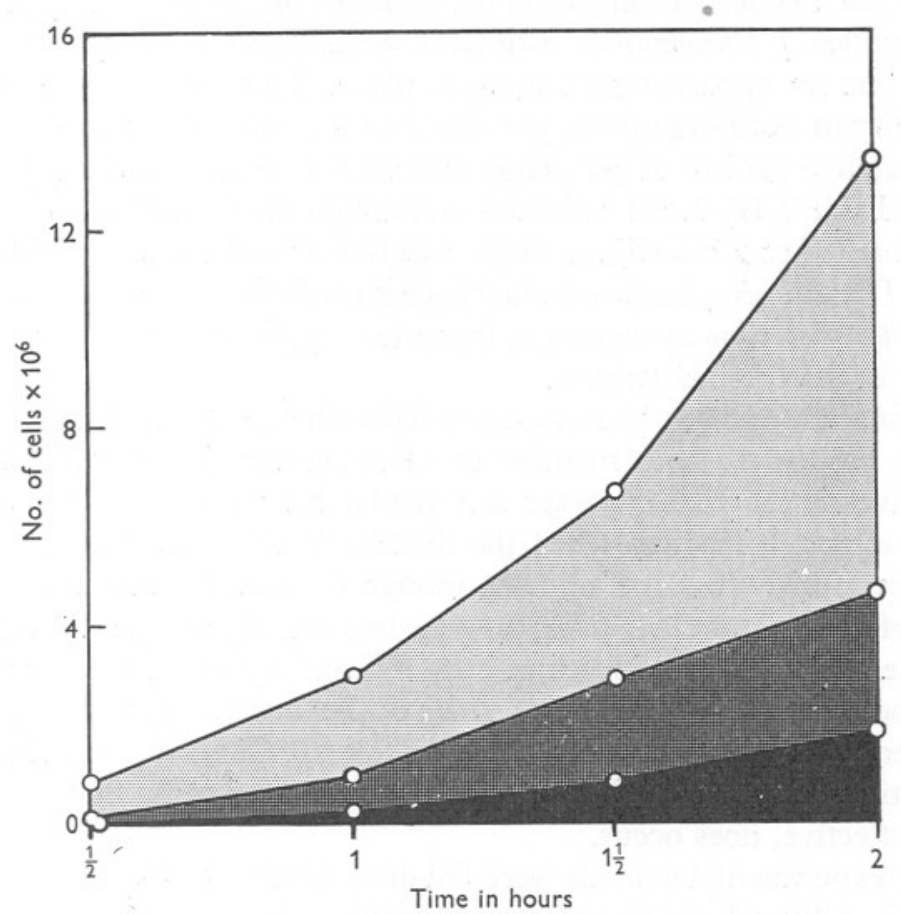

Fig. Io. Cumulative numbers of Phaeodactylum cells filtered, ingested and digested over a period of $2 \mathrm{~h}$ in the experiments referred to on p. 252. Black area represents digested cells, dark stipple the intact cells within the stomach, light stipple the cells rejected as pseudofaeces, and the unshaded area cells remaining unfiltered.

In (a) (Table IX) proportions of the two organisms in the supernatant were estimated before and after the animal had filtered, and, as might have been expected, no significant differences were found, i.e. no selection takes place between organisms as they enter the inhalant siphon. If any noxious or toxic substance is present the animal evidently ceases filtering and closes the shell (see p. 247, Gymnodinium veneficum). In (b) (Table X) estimates of the proportions of the two organisms were made in the original mixture and in the 
resuspended pseudofaeces after $6 \mathrm{~h}$ feeding. This would give a measure of the sorting by the gills and labial palps, after filtration, but before entry into the mouth. There appears to be a significantly greater proportion of Peridinium in the pseudofaeces, and therefore some selection of Dicrateria in the food taken in. From experimental results below (Tables XII and XV) we know that Peridinium is indigestible, and, further, is much larger $(25 \mu)$ than Dicrateria $(5 \mu)$. There is thus the interesting possibility that sorting by size and weight may take place; it would be desirable, however, to do further experiments before concluding that this type of sorting between different organisms plays an important part in the economy of Lasaea. ${ }^{1} \operatorname{In}(c)$ (Table XI) (Phaeodactylum / Chromulina) estimates were made as in (b), after io $\mathrm{h}$ filtering, but no apparent sorting took place. This would agree with the acceptability of both organisms presented singly and with the absence of an easily sortable organism of very large size such as Peridinium in (b).

In $(d)$ (Table XII) direct estimates were made from the stomach contents of the Lasaea after $2 \mathrm{~h}$ feeding. Here selection at first sight appears to be in favour of Thalassiosira, but when allowance is made for the total disappearance of some Phaeodactylum by digestion, the ratio may not be significantly different from that in the original culture.

In the final experiment (e) Lasaea was fed with a mixture of Phaeodactylum and large empty diatom frustules of 'Kieselguhr' (diatomaceous earth). Quantitative determinations were not made, but animals were fixed and sectioned after $2 \mathrm{~h}$ feeding, when the distribution of 'Kieselguhr' could be followed carefully. In some animals, though not all, the stomach contained particles of ' Kieselguhr' reaching $30-35 \mu$ in size. By far the greater part of the ingested material was a mass of pure Phaeodactylum, while the rejecting areas of the gill margin, labial palps, sides of the foot and ventral edges of the mantle were heavily loaded with diatom fragments. It is clear that, in a heavy concentration of Phaeodactylum and large diatom fragments, sorting, though not fully effective, does occur.

Further experimental animals were fed on a mixture of Phaeodactylum and 'Aquadag'. Although the present writers would agree with MacGinitie (I94I) that this substance produces unnatural feeding behaviour, there is evidently no barrier to its ingestion. Large masses of 'Aquadag' were found embedded in mucus in the stomachs of sectioned animals. The 'Aquadag' did not appear to disperse within the stomach, but to pass in a compact bolus directly to the intestine.

1 The Peridinium/Dicrateria mixture was presented in 'thin' culture so that the fraction taken into the gut and that rejected in the pseudofaeces might be of comparable order of size. Thus any difference in the proportions of the two organisms ingested are unlikely to be obscured by a markedly greater bulk of pseudofaeces. 
TABle IX. Proportions of PhaEOdACTYLUM tRICORNUTUM AND DICRATERIA INORNATA REMAINING IN THE SUPERNATANT AFTER $6 \mathrm{H}$ FILTERING

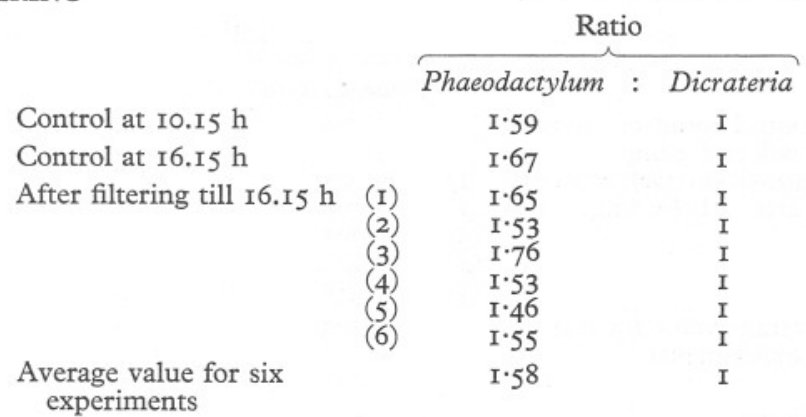

Table X. Proportions of Peridinium trochoideum and DicRateria INORNATA IN THE ReSUSPENDED PSEUdOFAeCES AFTER 6 H FilteRING

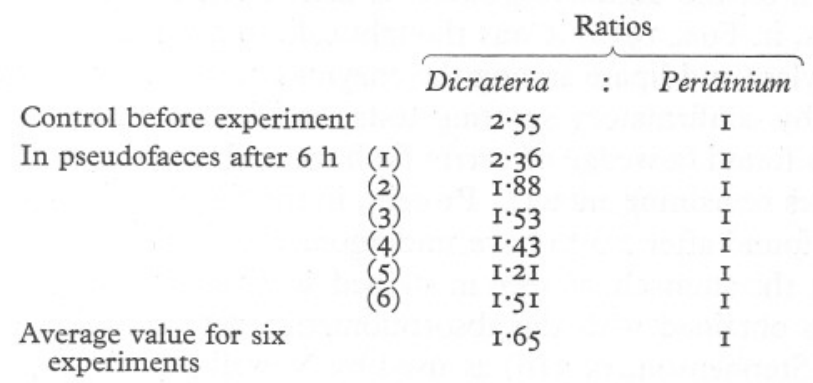

Table XI. Proportions of PhaEOdactylum tRICORNUTUM and Chromulina pusilla, in the Resuspended Pseudofaeces after IO H FILTERING

\begin{tabular}{|c|c|c|c|}
\hline & & Rat & ios \\
\hline & & Phaeodactylum & : Chromulina \\
\hline Control before experiment & & I.7 & I \\
\hline In pseudofaeces after ro h & (I) & $2 \cdot I$ & I \\
\hline & (2) & $\mathrm{I} \cdot 98$ & I \\
\hline & (3) & I. 49 & I \\
\hline & (4) & $2 \cdot 3$ & I \\
\hline & (5) & $\mathrm{I} \cdot 92$ & I \\
\hline Average value for six & & $\begin{array}{l}\mathrm{I} \cdot 47 \\
\mathrm{I} \cdot 88\end{array}$ & $\begin{array}{l}\text { I } \\
\text { I }\end{array}$ \\
\hline experiments & & & \\
\hline
\end{tabular}


TABle XII. Proportions of PhaEODACTYLUM tRICORNUTUM AND THALASSIOSIRA FLUVIATILIS IN THE STOMACH CONTENTS OF LASAEA RUBRA AFTER 2 H FEEDING

\begin{tabular}{|c|c|c|c|}
\hline \multirow[b]{3}{*}{$\begin{array}{l}\text { Control count of mixture } \\
\text { before feeding }\end{array}$} & & \multicolumn{2}{|c|}{ Ratios } \\
\hline & & Phaeodactylum & : Thalassiosira \\
\hline & & $7 \cdot 6$ & I \\
\hline Ratio in stomach contents & (I) & 5.5 & I \\
\hline after $2 \mathrm{~h}$ feeding & (2) & $7 \cdot 5$ & I \\
\hline & (3) & $6 \cdot 5$ & I \\
\hline & (4) & $4 \cdot 6$ & I \\
\hline & (5) & $7 \cdot 5$ & I \\
\hline $\begin{array}{l}\text { Average value for five } \\
\text { experiments }\end{array}$ & & $6 \cdot 3$ & I \\
\hline
\end{tabular}

\section{Digestive Activity}

Estimation of the digestive powers of Lasaea rubra was approached in two ways. First, the enzymic activity of a centrifuged homogenate of the whole animals was tested, using methods cited in Stephenson (1939). From much previous work on the digestive powers of lamellibranchs (see Yonge, I926; Fox \& Marks, in Fox, 1936) it was thought safe to assume the presence of a protease, amylase and lipase among the enzymes of the digestive gland. This was verified by confirmatory spotting tests, and in addition a slowly acting pectinase was found (a wedge of carrot flesh was reduced to pulp after 7 days, control wedges remaining intact). Protein, in the form of dogfish blood corpuscles, was found after $2 \mathrm{~h}$ to have undergone extracellular digestion within the lumen of the stomach, as seen in stained sections of Lasaea. After I2 $\mathrm{h}$ no result was obtained with the absorptiometric determination of cellulase activity (see Stephenson, p. 316) as used by Newell (1953) with Ostrea.

Secondly, the stomach contents of Lasaea were examined at intervals after feeding with possible natural foods. Experiments of the classical kind, using artificial 'type' substrates, such as cotton-wool, filter-paper and fibrin, in incompletely controlled conditions in vitro, seemed less likely to give an exact picture of the animal's natural digestion. The condition of the gut contents at stated times after feeding with the flagellates Isochrysis galbana and Peridinium trochoideum, and with Phaeodactylum tricornutum and Thalassiosira fluviatilis is shown in Tables XIII-XV. These results show a rapid and complete digestion of Isochrysis and Phaeodactylum. Whatever the true structure of the wall of Phaeodactylum (see Wilson, 1946, and Hendey, 1954) it is evidently very easily attacked by digestion to release the protoplasmic contents of the cell. The majority of ingested Phaeodactylum had become 'ghosts' in $45 \mathrm{~min}$ (Table XIV). Easy digestion of these two organisms is accompanied by rapid filtration, and they seem likely to be a nearly ideal food.

By contrast with these easily digested organisms we have the results using a heavily walled diatom, Thalassiosira, and an armoured dinoflagellate, 
Peridinium. Peridinium is not digested, nor is this surprising, as its digestion would require a cellulase, which Lasaea lacks. Further, there is a correlation between low filtering rate and indigestibility. With Thalassiosira it was found difficult to make reliable absorptiometric measurements of uptake by Lasaea, as its normal habit in thick culture is to lie in a sludge close to the bottom of

\section{Table XiII. Condition of the Gut Contents of LasaEa Fed with VARIOUS ORGANISMS}

\begin{tabular}{|c|c|c|}
\hline \multicolumn{3}{|c|}{ (Examined in sectioned and stained material.) } \\
\hline no. & Feeding & Gut contents \\
\hline I & I $\mathrm{h}$ in Peridinium trochoideum & $\begin{array}{l}\text { Stomach-cell walls of Peridinium all intact, } \\
\text { many organisms still containing organized } \\
\text { stainable protoplasm, somewhat shrunk due to } \\
\text { fixation. No digestion. Intestine-well recog- } \\
\text { nizable cell walls with contents. No digestion }\end{array}$ \\
\hline 2 & I h in $P$. trochoideum & $\begin{array}{l}\text { Intestine-little evidence of digestion. Cell-wall } \\
\text { plates still clearly recognizable }\end{array}$ \\
\hline 3 & $\begin{array}{l}2 \mathrm{~h} \text { in Phaeodactylum tricor- } \\
\text { nutum }^{\star}\end{array}$ & $\begin{array}{l}\text { Stomach-filled entirely with 'ghost' cells. In a } \\
\text { few cells a bluish staining material (azan), } \\
\text { probably leucosin rather than protoplasm, } \\
\text { remains (see Hendey, I954). Digestion com- } \\
\text { plete. Digestive gland lumen entirely filled } \\
\text { with 'ghost' cells in same condition as those in } \\
\text { stomach. Intestine - 'ghost' cells even more } \\
\text { eroded than in stomach. Digestion complete }\end{array}$ \\
\hline 4 & $2 \mathrm{~h}$ in Isochrysis galbana & $\begin{array}{l}\text { Stomach - no trace of organized protoplasm or } \\
\text { intact cells. Digestion complete }\end{array}$ \\
\hline 5 & $2 \mathrm{~h}$ in $I$. galbana & Stomach - digestion complete as in (4) \\
\hline 6 & $2 \mathrm{~h}$ in Thalassiosira fluviatilis & $\begin{array}{l}\text { Stomach and intestine - only a few cells digested, } \\
\text { majority intact }\end{array}$ \\
\hline 7 & $2 \mathrm{~h}$ in $T$. fluviatilis & $\begin{array}{l}\text { Stomach and intestine -little digestion. Some cells } \\
\text { appear empty, but there is little breakdown of } \\
\text { cell contents, even in faeces. Cell walls are } \\
\text { always clearly defined. Digestion is apparently } \\
\text { very slow, and the majority of cells are passed } \\
\text { in faeces before digestion }\end{array}$ \\
\hline 8 & $2 \mathrm{~h}$ in $T$. fluviatilis & $\begin{array}{l}\text { Less digestion than in (7). Almost all the cells } \\
\text { show clearly defined protoplasmic contents }\end{array}$ \\
\hline 9 & $2 \mathrm{~h}$ in $T$. fluviatilis & $\begin{array}{l}\text { Stomach-contained relatively few diatoms, } \\
\text { showing only slight traces of digestion }\end{array}$ \\
\hline Io & $2 \mathrm{~h}$ in $T$. fluviatilis & $\begin{array}{l}\text { Stomach-diatoms almost all undigested. } \\
\text { Intestine-faeces formed of compacted masses } \\
\text { of cells, mostly quite undigested }\end{array}$ \\
\hline
\end{tabular}

the vessel, though it is easily stirred into suspension and can thus become available for short periods for filtering. It is found that Lasaea can slowly digest Thalassiosira, presumably with the aid of the pectinase in the digestive gland, which would aid in separation of the siliceous valves. The process is, however, very slow, and it seems likely that diatoms are not in nature a good or sufficient food. 


\section{Table XiV. Condition of the Stomach and Intestine Contents of LASAEA RUBRA AFTER FEEDING WITH PHAEODACTYLUM TRICORNUTUM}

\begin{tabular}{|c|c|c|c|c|c|c|c|c|}
\hline $\begin{array}{l}\text { Animal } \\
\text { no. }\end{array}$ & $\begin{array}{l}\text { Time after } \\
\text { feeding }\end{array}$ & & & & $\begin{array}{l}\text { unts of } \mathrm{c} \\
0.1 \mathrm{~mm} \\
\text { ter dilutic }\end{array}$ & & $\begin{array}{l}\text { Total in } \\
\text { stomach in } \\
\text { thousands }\end{array}$ & Remarks \\
\hline I & $45 \mathrm{~min}$ & Stomach & $\begin{array}{l}\text { Whole cells } \\
\text { 'ghosts' }\end{array}$ & $\begin{array}{l}48 \\
64\end{array}$ & $\begin{array}{ll}56 & 28 \\
76 & 80\end{array}$ & $\begin{array}{l}32 \\
64\end{array}$ & $\begin{array}{r}82 \\
142\end{array}$ & $\begin{array}{l}\text { Most of the 'ghost' cells } \\
\text { heavily eroded, visible } \\
\text { only with difficulty }\end{array}$ \\
\hline \multirow{3}{*}{2} & \multirow{3}{*}{ I h $20 \mathrm{~min}$} & Faeces & $\begin{array}{l}\text { Whole cells } \\
\text { 'ghosts' }\end{array}$ & $\begin{array}{l}24 \\
28\end{array}$ & $\begin{array}{ll}44 & 56 \\
52 & 56\end{array}$ & $\begin{array}{l}76 \\
76\end{array}$ & - & $\begin{array}{l}\text { Also much detritus re- } \\
\text { maining from before } \\
\text { feeding with Phaeo- } \\
\text { dactylum }\end{array}$ \\
\hline & & Stomach & $\begin{array}{l}\text { Whole cells } \\
\text { 'ghosts' }\end{array}$ & $\begin{array}{l}16 \\
30\end{array}$ & $\begin{array}{l}8 \\
20\end{array}$ & & $\begin{array}{l}24 \\
50\end{array}$ & - \\
\hline & & Faeces & $\begin{array}{l}\text { Whole cells } \\
\text { 'ghosts' }\end{array}$ & $\begin{array}{l}\circ \\
4\end{array}$ & & & - & $\begin{array}{l}\text { Faeces with large no. of } \\
\text { flagellates and detritus, } \\
\text { in addition to Phaeo- } \\
\text { dactylum }\end{array}$ \\
\hline 3 & I h $45 \mathrm{~min}$ & Stomach & $\begin{array}{l}\text { All digested } \\
\text { to an ad- } \\
\text { vanced stage }\end{array}$ & & 一 & & $32^{\star}$ & $\begin{array}{l}\text { No cells remaining with } \\
\text { contents and 'ghosts' } \\
\text { much further digested } \\
\text { than in I and } 2 \text {-only } \\
\text { visible with difficulty }\end{array}$ \\
\hline 4 & $2 \mathrm{~h}$ & Stomach & $\begin{array}{l}\text { Whole cells } \\
\text { 'ghosts' }\end{array}$ & $\begin{array}{r}2 \\
18\end{array}$ & $\begin{array}{r}4 \\
17\end{array}$ & & $4 I^{\star}$ & - \\
\hline 5 & $2 \mathrm{~h} \mathrm{I} 5 \mathrm{~min}$ & Stomach & $\begin{array}{l}\text { Whole cells } \\
\text { 'ghosts' }\end{array}$ & $\begin{array}{r}6 \\
28\end{array}$ & $\begin{array}{r}7 \\
34\end{array}$ & & $75^{\star}$ & for \\
\hline 6 & $2 \mathrm{~h} 30 \mathrm{~min}$ & Stomach & $\begin{array}{l}\text { Whole cells } \\
\text { 'ghosts' }\end{array}$ & $\begin{array}{r}5 \\
22\end{array}$ & $\begin{array}{r}6 \\
18\end{array}$ & & $5 \mathrm{I}^{\star}$ & $\begin{array}{l}\text { 'Ghost' cells as fully } \\
\text { digested as possible } \\
\text { while still remaining } \\
\text { visible }\end{array}$ \\
\hline
\end{tabular}

* 'Ghost' and whole cells not estimated separately in total in stomach.

\section{Discussion}

\section{Filtering Rates}

Although all of the animals, so far as could be detected, kept their valves open and siphons out for most of the experimental period, an important cause of the variations in filtering rate recorded must have been the temporary cessation of activity of some of the animals. An attempt has been made to reduce these variations as far as possible by using 20 animals in each experiment and performing as many experiments as was practicable. It is also thought probable that the highest filtering rates have the greatest significance, and approximate most closely to a natural filtering rate in the field. On this basis, the filtering rate of Lasaea in Phaeodactylum compares closely with that of an adult ( $74 \mathrm{~mm})$ Mytilus californianus, as estimated by the indirect method of Fox et al. (1937) (see Table II). A similar order of values was reported by Willemsen (I952) in adult Cardium edule and Mytilus edulis by a method very closely comparable to the one used here. Smaller specimens of Mytilus edulis have shown a faster 
Table XV. Condition of the Stomach Contents of LASAEA RUbra, After FeEding With PERIDINIUM TROCHOIDEUM AND THALASSIOSIRA FLUVIATILIS

(Stomachs were dissected from living animals, contents diluted to $0.2 \mathrm{ml}$. with seawater, and counts made.)

I. Peridinium trochoideum

\begin{tabular}{|c|c|c|c|c|c|c|c|}
\hline $\begin{array}{c}\text { Animal } \\
\text { no. }\end{array}$ & Fed (h) & Cells & $\begin{array}{l}\text { Coun } \\
\mathrm{I} \mathrm{m^{3 }}\end{array}$ & $\begin{array}{l}\text { ts of } \\
\text { afte }\end{array}$ & $\begin{array}{l}f \mathrm{ce} \\
\mathrm{er} d\end{array}$ & $\begin{array}{l}\text { lls in } \\
\text { ilution }\end{array}$ & $\begin{array}{l}\text { Estimated total cells } \\
\text { in stomach }\end{array}$ \\
\hline I & I & $\begin{array}{l}\text { Cells with walls and } \\
\text { contents intact }\end{array}$ & 9 & & & 4 & 1050 \\
\hline & & Cells empty & - & - & - & - & 0 \\
\hline 2 & I & $\begin{array}{l}\text { Intact } \\
\text { Empty }\end{array}$ & $\underline{5}$ & $\begin{array}{l}\mathrm{I} \\
\mathrm{I}\end{array}$ & $\begin{array}{l}4 \\
\mathrm{I}\end{array}$ & I & $\begin{array}{l}550 \\
100\end{array}$ \\
\hline 3 & I & $\begin{array}{l}\text { Intact } \\
\text { Empty }\end{array}$ & I & $\stackrel{I}{-}$ & $\overline{-}$ & - & c. 100 ? \\
\hline 4 & I & $\begin{array}{l}\text { Intact } \\
\text { Empty }\end{array}$ & $\underline{4}$ & I & I & - & $\begin{array}{r}300 \\
0\end{array}$ \\
\hline 5 & 2 & $\begin{array}{l}\text { Intact } \\
\text { Empty }\end{array}$ & $7^{\star}$ & & $\underline{4}$ & 2 & $\begin{array}{r}850 \\
0\end{array}$ \\
\hline 6 & $3 \frac{1}{2}$ & $\begin{array}{l}\text { Intact } \\
\text { Empty }\end{array}$ & $\underline{4}$ & $\begin{array}{l}I \\
-\end{array}$ & I & - & $\begin{array}{r}300 \\
0\end{array}$ \\
\hline 7 & $3^{\frac{1}{2}}$ & $\begin{array}{l}\text { Intact } \\
\text { Empty }\end{array}$ & $\underline{5}$ & $\begin{array}{l}6 \\
-\end{array}$ & 3 & $\underline{4}$ & $\begin{array}{r}900 \\
0\end{array}$ \\
\hline
\end{tabular}

\section{Thalassiosira fluviatilis}

\begin{tabular}{|c|c|c|c|c|c|c|c|}
\hline \multirow{3}{*}{$\begin{array}{c}\text { Animal } \\
\text { no. } \\
\text { I }\end{array}$} & \multirow{3}{*}{$\begin{array}{c}\text { Fed (h) } \\
\text { I }\end{array}$} & Cells & \multicolumn{4}{|c|}{$\begin{array}{l}\text { Count of cells in } \\
\mathrm{r} \mathrm{mm}^{3} \text { after dilution }\end{array}$} & \multirow{2}{*}{$\begin{array}{c}\text { Estimated total cells } \\
\text { in stomach } \\
250\end{array}$} \\
\hline & & $\begin{array}{l}\text { Frustules with con- } \\
\text { tents intact }\end{array}$ & 2 & 2 & - & I & \\
\hline & & Frustules empty^ & I & - & - & - & 50 \\
\hline 2 & I & $\begin{array}{l}\text { Intact } \\
\text { Empty }\end{array}$ & I & I & $\begin{array}{l}\mathrm{I} \\
\mathrm{I}\end{array}$ & - & $\begin{array}{r}150 \\
50\end{array}$ \\
\hline 3 & 2 & $\begin{array}{l}\text { Intact } \\
\text { Empty }\end{array}$ & I & - & - & - & $\begin{array}{l}\text { Very few taken into } \\
\text { stomach }\end{array}$ \\
\hline 4 & 2 & $\begin{array}{l}\text { Intact } \\
\text { Empty }\end{array}$ & 2 & $\begin{array}{l}\text { I } \\
\text { I }\end{array}$ & $\overline{-}$ & $\begin{array}{l}\text { I } \\
\text { I }\end{array}$ & $\begin{array}{l}200 \\
100\end{array}$ \\
\hline 5 & $2 \frac{1}{2}$ & $\begin{array}{l}\text { Intact } \\
\text { Empty }\end{array}$ & $\underline{4}$ & $\begin{array}{l}2 \\
2\end{array}$ & $\overline{-}$ & $\overline{-}$ & $\begin{array}{l}300 \\
100\end{array}$ \\
\hline 6 & $2 \frac{1}{2}$ & $\begin{array}{l}\text { Intact } \\
\text { Empty }\end{array}$ & $\begin{array}{l}2 \\
2\end{array}$ & $\begin{array}{l}2 \\
1\end{array}$ & $\overline{-}$ & $\begin{array}{l}3 \\
3\end{array}$ & $\begin{array}{l}350 \\
300\end{array}$ \\
\hline 7 & $4 \frac{1}{2}$ & $\begin{array}{l}\text { Intact } \\
\text { Empty }\end{array}$ & $\underline{4}$ & $\begin{array}{l}3 \\
2\end{array}$ & $\begin{array}{l}2 \\
I\end{array}$ & I & $\begin{array}{l}500 \\
200\end{array}$ \\
\hline 8 & $4 \frac{1}{2}$ & $\begin{array}{l}\text { Intact } \\
\text { Empty }\end{array}$ & $\begin{array}{l}4 \\
5\end{array}$ & $\begin{array}{l}3 \\
4\end{array}$ & $\begin{array}{l}3 \\
I\end{array}$ & $\begin{array}{l}2 \\
I\end{array}$ & $\begin{array}{l}600 \\
550\end{array}$ \\
\hline 9 & $4 \frac{1}{2}$ & $\begin{array}{l}\text { Intact } \\
\text { Empty }\end{array}$ & $\begin{array}{l}7 \\
2\end{array}$ & $\begin{array}{l}3 \\
3\end{array}$ & $\begin{array}{l}6 \\
I\end{array}$ & $\begin{array}{l}6 \\
2\end{array}$ & $\begin{array}{r}1100 \\
400\end{array}$ \\
\hline IO & I6 & $\begin{array}{l}\text { Intact } \\
\text { Empty }\end{array}$ & I & - & I & I & $\begin{array}{r}150 \\
50\end{array}$ \\
\hline II & I6 & $\begin{array}{l}\text { Intact } \\
\text { Empty }\end{array}$ & $\overline{\mathrm{I}}$ & I & I & I & $\begin{array}{r}150 \\
50\end{array}$ \\
\hline I2 & I6 & $\begin{array}{l}\text { Intact } \\
\text { Empty }\end{array}$ & $\begin{array}{l}6 \\
\text { I }\end{array}$ & $\begin{array}{l}3 \\
\mathrm{I}\end{array}$ & $\begin{array}{l}\text { I } \\
\text { I }\end{array}$ & - & $\begin{array}{l}500 \\
150\end{array}$ \\
\hline I3 & I6 & $\begin{array}{l}\text { Intact } \\
\text { Empty }\end{array}$ & I & $\begin{array}{l}I \\
2\end{array}$ & $\overline{\mathrm{I}}$ & I & $\begin{array}{l}150 \\
150\end{array}$ \\
\hline
\end{tabular}

* Sample counts of original thick culture for proportion of empty frustules: intact frustules I: 5 . 
rate, Jørgensen's figures giving ratios of $c .200$ and 150 with animals 15 and $30 \mathrm{~mm}$ long respectively. Jørgensen appears to have calculated rates over relatively short periods of up to $\mathrm{I} h$. All the Lasaea calculations are, however, for rates uniformly sustained for at least $3 \mathrm{~h}$. The high initial rate almost always obtained by Jørgensen with single Mytilus was never observed in Lasaea. Much higher values were also twice reported with oysters, when the direct method of measuring water pumped out of the exhalant aperture of the pallial cavity was used. Here, if the volume of the animals has been estimated correctly in Table II, the ratio is considerably higher than with the indirect method of measuring filtration.

Control experiments were carried out to determine whether variations in the density of the culture had any effect on the filtering rate. Loosanoff \& Engle (1947) suggest that in conditions of high turbidity, feeding, as distinct from filtering, might cease in oysters. Variation in concentration of Phaeodactylum produced no significant difference in filtering rates, though in dense cultures the output of pseudofaeces is markedly increased. In the experiments with various flagellates recorded above, no correlation could be found between initial density of the experimental culture and the rate of filtering. It seems likely that a high filtering rate can be maintained at the highest densities used in these experiments, as will be seen from the values with Chromulina and Isochrysis, which were both used in thick cultures. On the other hand, a thin Prorocentrum culture was filtered almost as rapidly as the dense Isochrysis. Thus, with pure suspensions of food organisms, the density of the suspension appears to be without effect on the filtering rate.

Of the variations in filtering rate recorded with different organisms, perhaps the most striking result was obtained with the naked dinoflagellate Gymnodinium veneficum, in which no sustained filtering was observed at all. The remaining organisms may be arranged-by comparison with Phaeodactylum in two groups. First, Nannochloris atomus, Chlorella stigmatophora, Peridinium trochoideum and Dicrateria inornata were filtered at rates significantly lower than that for Phaeodactylum. With each of the remaining flagellates, namely Isochrysis galbana, Exuviaella baltica, Chromulina pusilla and Prorocentrum micans, the average rate was faster than that for Phaeodactylum. The most rapidly filtered organism in any of the experiments was Isochrysis galbana, the fastest rate with this flagellate being $2 \cdot 18 \mathrm{I} \mathrm{ml}$./ $\mathrm{h}$ for 20 animals. The fastest rates with Chromulina pusilla, Exuviaella baltica and Prorocentrum micans were respectively $2 \cdot \mathrm{I} 2, \mathrm{I} \cdot \mathrm{I} 84$ and $\mathrm{I} \cdot 365$.

It will have been noted that micro-organisms were always presented to the animals at concentrations greatly exceeding those ever present in the sea; and the criticism might be made that the experimental results establish nothing more than the reaction of Lasaea to a series of unialgal cultures at artificially high concentrations. There are, however, several indications that the preferences disclosed may have some reality under natural conditions. Thus, with 
the toxic Gymnodinium veneficum no filtering was obtained, and with $G$. vitiligo and Chlorella stigmatophora, both suspected by Bainbridge (1953) of mild toxicity, low filtering rates were recorded. However, Dicrateria and the minute Nannochloris, which also gave low rates, have never been suspected of toxicity. A recent report by Pinto (I953) states that Exuviaella baltica and Prorocentrum micans have both been found toxic in 'red water', but in our experiments using the Plymouth strains of these organisms we have found no evidence of toxicity. The filtering rates with these organisms were among the highest obtained.

Of the other flagellates filtered rapidly by Lasaea rubra, Isochrysis galbana has repeatedly been found highly acceptable as food to cultures of filterfeeding animals. Chromulina pusilla, a species also filtered rapidly, is probably identical with the $\mathrm{I}-2 \mu$ component of the phytoplankton that evidently contributes heavily to the natural food of Lasaea (Table XVI). With Peridinium trochoideum, on the other hand, there appears to be a correlation between low filtering rate and lack of digestibility (see Table XV).

Any differences in pumping-rate resulting from the different sizes of the organisms, and consequent higher efficiency of filtering large organisms, appear to be unlikely. Small Chromulina $(\mathrm{I}-2 \mu)$ were in fact filtered rapidly, large Peridinium $(25 \mu)$ slowly. Nor could any correlation be found by plotting the sizes of each of the various species of flagellates against the respective filtering rates obtained.

No figures appear to exist for exact comparison of the filtering rates of other lamellibranchs with different types of flagellates. Jørgensen (I949) carried out experiments with Mytilus, using, in addition to Phaeodactylum, the flagellates Dicrateria inornata and Isochrysis galbana. He used single specimens of Mytilus of lengths I.5, 2.9 and $3.2 \mathrm{~mm}$, but his experiments, being not primarily directed towards this point, appear to be too few in number, and the results to fluctuate over too wide a range, to allow significant correlation of feeding rate with type of organism.

Further experiments might well be carried out on filtration rates with various organisms, and on possible mechanisms of discrimination. Bainbridge (I953) studied the effects of various phytoplanktonic organisms on planktonic animals, but little seems to have been done on the relation of sedentary benthic animals to particular constituents of the phytoplankton. With Lasaea itself nothing is yet known of the way in which the presence of a particular kind of flagellate exerts its effect on filtering rate. There may be different effects on the rate of beat of the gill cilia, different degrees of contraction of the gill mesh, or variations in the proportion of time engaged in filtering. It is hoped to carry out further experiments on some of these points with the use of a larger bivalve such as Mytilus. Of particular interest as a first study would be the direct observation of the action of various phytoplankton cultures on ciliary beat. 


\section{The Filtering Efficiency of the Gill}

Jørgensen (1949) and Jørgensen \& Goldberg (1953) discuss the mechanism of collection and transport of food particles by the lamellibranch gill, and whether this takes place by a continuous mucous sheet moving over the gill surface, as suggested by MacGinitie (I94I), or with the aid of only a small amount of mucus. Using Mytilus edulis, Jørgensen (1949) found that, under certain conditions, graphite particles were filtered down to $\mathrm{I}-2 \mu$ in size, and at other times the majority of the $<5 \mu$ particles were rejected. He explains these differences by the presence or absence of a 'mucous net' constituting a fine filter upon the surface of the gill. When feeding takes place by this net, particles become intercepted by the mucus and little or no selection according to particle size is possible. Under certain conditions, however, the smaller sizes of graphite particles are allowed to pass through the gill ostia in the absence of a mucous net, at which times filtration will take place merely by the gill ostia or the efficiency of the straining cilia. Later Jørgensen \& Goldberg (1953) found retention in Ciona and in Mytilus of graphite particles of I-2 $\mu$. In Crassostrea virginica, $2-3 \mu$ particles were retained, while $\mathrm{I}-2 \mu$ particles appeared to pass through the gill. It was assumed that in Ciona and Mytilus a mucous net contributed to food collecting, after the manner described by MacGinitie, and that in Crassostrea the filtering efficiency of the gill was decreased in the absence of mucus.

Our experiments with Chromulina pusilla ( $\mathrm{I}-2 \mu$ diameter) and with bacteria showed no evidence of a falling off in efficiency of filtering in Lasaea with smaller particle size. With one exception, the $5 \mu$ flagellate Isochrysis galbana, the rates with Chromulina were the highest recorded. The great potential value of these small and unarmoured forms seem to necessitate a high retentive efficiency of the gill, since it is likely that Lasaea feeding in nature must derive a high proportion of its food from abundant flagellates of this size (see Table XVI).

Jørgensen (1949) found evidence that Mytilus at times rejected 'Aquadag'. In general Lasaea rubra took up 'Aquadag' very vigorously over experimental periods of $5 \mathrm{~h}$, sometimes at a rate as fast as any recorded with flagellates. Freshly made up 'Aquadag' gave contradictory results. In one set of experiments, the same effect was obtained as by Jørgensen \& Goldberg (I953); 'new' 'Aquadag', made up for not more than $\mathrm{I} h$ was poorly filtered, while 'old' 'Aquadag' that had been left to stand for $7 \mathrm{~h}$ before use was filtered more than twice as fast. Jørgensen and Goldberg ascribed this effect to the tendency of particles to form larger aggregates on standing. In Lasaea the efficient filtering of the smallest particles of 'Aquadag' is probably not conclusive evidence of the presence of a mucous net; and it seems that bivalves may be very differently sensitive at different times to stimulation or irritation by graphite. This irregularity contrasts with the constant and easily 
reproducible filtering rates obtained in Lasaea with suspension of natural foods.

The mesh size of the gill is by no means easy to determine in fixed and contracted sections. In Lasaea rubra, moreover, neither the secretion of a mucous net nor the contraction of the gill ostia may in fact be necessary to retain small flagellates. A far more efficient means of entrapping particles at the frontal surface seems to be the fine fringes of eu-latero-frontal and prolatero-frontal cilia, which are very highly developed in Lasaea (see the papers of Atkins, 1936, 1938, for lamellibranchs in general; and Oldfield's recent work, I955, on Lasaea rubra). In previous discussions about the mucous net, the presence of these filtering cilia has been largely ignored, only Verwey (I952) having called attention to their use. Further, there is the strong objection to the mucous-net theory, that such a continuous sheet covering the gill would impede or prevent the action of the elaborate systems of sorting cilia. Jørgensen (I949) has recognized this difficulty; no one has satisfactorily answered it. However valuable MacGinitie's work in this field may be, his interpretation fails to reconcile the freedom of action of the sorting cilia with the employment of a continuous mucous net. It seems at least that efficient filtering can be carried out in the absence of a mucous net, and that the greatest stimulus to mucus secretion when it occurs may be the presence of large amounts of indigestible debris. Certainly, the lack of obvious mucus in many lamellibranchs, which sort particles on the gills and palps, is very striking in comparison with the large amounts of mucus in ciliary-feeding gastropods (Yonge, I938), Amphioxus and ascidians (Orton, I914), none of which have highly developed sorting mechanisms on the gill surface.

Tammes \& Dral, in a recent paper (I955), make a further criticism of McGinitie's theory of an 'ultra-sieve' and take the view that material may be retained by the gill, by a mechanism of adhesion to sticky cilia.

\section{Comparison of Filtering, Feeding and Digestion}

In a lamellibranch living in a high concentration of suspended material, it is important to distinguish three separate activities, filtering, feeding and digestion; and the rate of any of these functions will not necessarily be deducible from that of any other. It may be assumed that the formation of pseudofaeces in thick cultures is a consequence of the mechanical overloading of the gills and palps with a greater accumulation of particles than can be received into the gut (see Popham, I940, for details of rejectory mechanisms of the mantle cavity). Probably because of the great quantities filtered, the pseudofaeces of Lasaea were not compacted in strings as in Mytilus and Ostrea, but lay in a thick sludge, surrounding each cluster of bivalves, removed a little way from the animals by the force of the exhalant current. True faeces were produced in very much smaller amount than pseudofaeces, and had the form 
of compact oval pellets bound with mucus. Even in the thickest cultures that could be measured by the absorptiometer, it is unlikely that more than a very small fraction of organisms of Phaeodactylum size pass through the gill unfiltered; and in the present calculations this has been neglected and complete filtration assumed.

References in many papers to 'feeding' in lamellibranchs must clearly be interpreted as no more than 'filtering'. 'Food' is that which enters the mouth. Often, however, especially in experiments with 'thin' cultures, and probably as a general rule in natural sea water, feeding may approximate closely to filtering. It is also unsafe to speak of 'feeding' as equivalent to 'digestion'. Sometimes, such as in experiments using cultures, the amount of food digested may-with sufficient elapse of time-correspond to that ingested. But in other conditions, and probably in most situations in nature, much material can be shown to be ingested that will never be digested, either by reason of its own nature, or because of the overgorging of the animal's gut.

In several features Lasaea rubra appears to present an exception to the classical picture established by Yonge (I926) and later investigators of lamellibranch digestion. These aspects will be more fully discussed in a forthcoming paper. First, there is an entire lack of amoebocytic action within the stomach at any stage of digestion. Secondly, a large amount of extracellular digestion of phytoplanktonic organisms takes place within the stomach, before the products are absorbed, presumably for completion of digestion, by the digestive gland. In so far as this may involve proteolytic enzymes, it is thought that these must originate from the spheres passed into the stomach by holocrine fragmentation of the digestive cells. Probably in these features, as in much else, Lasaea is to be regarded as an exceptional lamellibranch, specialized by its small size and as a result of its 'difficult' habitat. It would certainly be unsafe to draw from it at this stage too many general conclusions about the nature of lamellibranch digestion.

\section{The Animal in Nature: Filtering Rate and Feeding Efficiency}

From several considerations it seems justifiable to regard the filtering rates observed with Phaeodactylum and some of the flagellates as not falling significantly short of the average natural rate. The animals used displayed normal visible activity and posture, and this was taken to imply normal filtering activity with little disturbance by experimental conditions. The relation of the volume of water filtered per hour to the volume of animal showed impressive agreement with figures recorded for other lamellibranchs (see Table II). Further, the filtering rate was found to vary predictably with temperature, with different kinds of flagellates, and in some cases with position on the shore (see below p. 27I). It was at least true that variations due to such factors as these were not masked by depressing factors operating as the result of laboratory conditions. 
It was also thought safe to assume that there is continuous filtering during the rather short period $(c .3 \mathrm{~h})$ that upper tidal Lasaea are normally submerged on the shore. In experiments lasting 8-ro $h$, little falling off in the rate of activity was observed.

The quantity and composition of material suspended in natural sea water, varies enormously with the locality, the phases of the tide, the season of the year and many other factors. Verwey (1952) provides a good dis-

\section{Table XVI. Estimates of Amounts of Living Organisms and Suspended Matter in Water Samples from Rocks below Plymouth Hoe}

(a) From surface sea water, a foot above the substratum (I2 August I954) and (b) from c. I cm above the surface of the substratum (20 September 1954).

\begin{tabular}{|c|c|c|c|c|c|}
\hline \multirow{5}{*}{$\begin{array}{l}\text { Organisms under } 2 \mu \\
\text { Organisms } 2-5 \mu \\
\text { Organisms } 5-\text { IO } \mu\end{array}$} & \multicolumn{5}{|c|}{ Counts per $\mathrm{I} \mathrm{mm}^{3}$ natural sea water } \\
\hline & (a) & \multicolumn{4}{|c|}{ (b) } \\
\hline & $60 \quad 48$ & 27 & $3^{8}$ & 37 & 29 \\
\hline & I 2 & 3 & 4 & 3 & 3 \\
\hline & -3 & I & - & - & 2 \\
\hline Totals & $6 \mathrm{I} 53$ & $3 I$ & 42 & 40 & 34 \\
\hline Over Io $\mu$ & $\begin{array}{l}\text { Much unidenti- } \\
\text { fiable organic } \\
\text { debris, sand } \\
\text { grains and } \\
\text { detritus }\end{array}$ & $\begin{array}{l}\text { Skeletoneme } \\
\text { loid diato } \\
\text { cean flagel } \\
\text { fragments } \\
\text { and 'Ectoc } \\
\text { unidentifia }\end{array}$ & $\begin{array}{l}\text {; se } \\
\text { ns; } \\
\text { ates } \\
\text { of } \\
\text { arpu: } \\
\text { ble c }\end{array}$ & $\begin{array}{l}\text { veral } \\
3 \text { ch } \\
\text { I eu } \\
\text { Enter } \\
\text { s'; ar } \\
\text { lebri }\end{array}$ & $\begin{array}{l}\text { nav } \\
\text { rysop } \\
\text { glen } \\
\text { omon } \\
\text { ad m } \\
\text { s }\end{array}$ \\
\hline
\end{tabular}

cussion of the causes of such variation. The figures provided in Table XVI were obtained by haemacytometer counts of centrifuged sea water in which Lasaea rubra was naturally feeding, on the Hoe Front at Plymouth. Two such counts are given, $(a)$ from sea water taken at the surface on an incoming tide, about a foot above the rocky bottom, and $(b)$ from sea water taken by pipetting from approximately $\mathrm{I} \mathrm{cm}$ above the surface of the rock. In composition and number of organisms these figures may be regarded as representative of water samples from near the substratum in the late summer. No information is at present available for other times of the year.

Any assessment of the annual food intake and the growth and metabolic requirements of Lasaea must await further work than is recorded here. We would now do no more than point out that, if we assume the late summer figures for density of phytoplankton given in Table XVI to approach a representative average for $\mathrm{I} 2$ months, and if we take the rate of filtering derived in this paper as coming close to the natural one in the field, then-working from living flagellates and diatoms alone-we find an annual food intake of no more than $c .0 .07 \mathrm{mg}$ for an animal weighing $\mathrm{I} \cdot 0 \mathrm{mg}$. This figure, which-as was found by Fox \& Coe (1943) with similar calculations for Mytilus-is obviously 
inadequate, neglects other important sources of food. There is first the considerable amount of organic detritus, revealed in Table XVI and in analyses of stomach contents, that must be stirred into suspension during feeding, and which it is difficult to estimate even in samples from near the bottom. While it is unlikely that Lasaea augments its suspended food by sucking up detritus directly from the bottom (neither the gill nor the inhalant siphon show any of the adaptations characteristic of deposit feeders-see Yonge, 1949), particles of debris must be constantly stirred into temporary suspension, and will appear in large amounts in the food of a suspension feeder. There is further the rich spring outburst of phytoplankton, at which time the greatest growth of Lasaea must occur; there is also the enormous crop of gametes liberated by intertidal algae, which may densely cloud the water for short periods. Finally, the effective filtering time must often be extended by the lodgment of splash in crevices containing Lasaea. Even two or three drops of splash may be enough to stir up significant quantities of detritus from the substratum and make it available for filtering. The smaller the amount of splash-within reasonable limits-the greater will be the concentration of the suspension filtered.

An analysis of the stomach contents of Lasaea rubra feeding on the Hoe Front (see Table XVII) is quite comparable with previous reports of food ingested by lamellibranchs (see, for example, Fox \& Coe, I943; Coe, I947). There is obvious difficulty in finding traces of minute or naked flagellates even a short time after their reception into the stomach, and the total of these ingested is best assumed to be the total amount present in, and filtered from, natural sea water. Their digestion by the animal is probably rapid and complete (see Table XIII). In addition, the stomach often contains diatoms sometimes of large size, up to $50 \mu$, either intact and little digested, or as open or broken frustules. Sponge spicules and siliceous spines of various kinds are a prominent item. Muchorganic detritus is also present, amorphous in nature, and almost always unidentifiable. In Lasaea, as in other lamellibranchs, it forms a normal part of the material taken into the stomach.

On the digestibility of organic debris it is difficult to assemble exact evidence. We have relied here on a careful examination of stomach contents and faeces in stained serial sections. Massive debris almost always appeared much less plentiful in the faeces than in the stomach contents. Faecal pellets were composed chiefly of fine broken spicules, occasional inorganic fragments such as small sand grains, and large diatom frustules, either empty or with stainable contents. It seems that some at least of the large fragments of organic detritus taken into the stomach are broken down by extracellular enzymes and perhaps assimilated. Some breakdown has probably taken place outside the animal by bacterial or autolytic action, and some of the products of this must be available to the animal. Lasaea is probably, however, without power to initiate the breakdown of cellulose walls (see results of the enzyme 
experiments, and experiments with Peridinium trochoideum, p. 259). Of diatoms, the experiments with Thalassiosira indicate that digestion is slower and sometimes incomplete; certainly some of these, as well as armoured dinoflagellates, must pass through the gut intact. The question of the availability of detritus to Lasaea is an important one, on which it is hoped to make further and more critical experiments.

\section{Table XVII. Examples of the Gut Contents of Typical LasaEA RUBRA, Collected from Rocks Below Plymouth Hoe after Several HOURS' FEEDING}

(Examined in fixed and stained serial sections.)

\begin{tabular}{|c|c|c|}
\hline Specimen & Region of gut & Remarks \\
\hline \multirow[t]{2}{*}{ I } & Stomach & $\begin{array}{l}\text { Large numbers of small, unidentifiable organisms, } \\
\text { corresponding in size to the } \mathrm{I}-2 \mu \text { flagellates of sea } \\
\text { water. A number of broken spicules as of sponges. } \\
\text { A diatom frustule, } c .20 \mu \text {, with no contents. A number } \\
\text { of frustules of small naviculoids. Little trace of } \\
\text { detritus, or unselected bottom deposits }\end{array}$ \\
\hline & Intestine & $\begin{array}{l}\text { A number of larger, inorganic particles, up to } 30 \mu \text { in } \\
\text { size, evidently rejected by the sorting area into the } \\
\text { intestine }\end{array}$ \\
\hline \multirow[t]{3}{*}{2} & Stomach & $\begin{array}{l}\text { A large amount of unorganized and unidentifiable } \\
\text { detrital material. Maximum size of particles, } c \text {. 20- } \\
30 \mu \text {. A good deal of organic (or colloidal) material, } \\
\text { staining pink with azan }\end{array}$ \\
\hline & Digestive diverticulum & No large or identifiable particles \\
\hline & Intestine & $\begin{array}{l}\text { Contents similar to stomach, including some large, } \\
\text { irregular particles and many small refractile specks }\end{array}$ \\
\hline \multirow[t]{2}{*}{3} & Stomach & $\begin{array}{l}\text { Many particles of amorphous, azan-staining, (? organic) } \\
\text { debris, particle size } 30 \mu \text { and less. Several frustules of } \\
\text { diatoms, empty, IO-I5 } \mu\end{array}$ \\
\hline & Intestine & $\begin{array}{l}\text { Diatom frustules, and several opaque, inorganic } \\
\text { particles }\end{array}$ \\
\hline \multirow[t]{3}{*}{4} & Stomach & $\begin{array}{l}\text { Large numbers of undetermined spicules, as of sponges, } \\
\text { with traces of broken diatom frustules. Small, highly } \\
\text { refractile, inorganic particles. A large Coscinodiscus } \\
\text { of } c .50 \mu \text { diameter, with stainable contents, apparently } \\
\text { not digested }\end{array}$ \\
\hline & Digestive diverticulum & No identifiable particulate contents \\
\hline & Intestine & $\begin{array}{l}\text { Spicules, detrital particles, and fragments of inorganic } \\
\text { material up to I5 } \mu \text { across. A large Coscinodiscus, } \\
\text { c. } 50 \mu \text { across, with the contents not digested }\end{array}$ \\
\hline
\end{tabular}

\section{Ecology: Intertidal Distribution}

Morton (1954), in a paper on the animals inhabiting intertidal crevices, has briefly discussed the ecology of Lasaea rubra. The species extends essentially throughout the intertidal zone, except the uppermost Littorina neritoides fringe. Its upper limit at Plymouth is at about the top of the Chthamalus barnacle zone, and it ranges downwards to low-water mark, as was pointed 
out by Glynne-Williams \& Hobart (1952). Morton has recorded that at Wembury it may just reach crevices in the zone of black lichen, Verrucaria maura, commenting that 'its presence here is a remarkable achievement for a lamellibranch relying on suspension feeding'.

There is in general a good correlation of shell size with length of time of

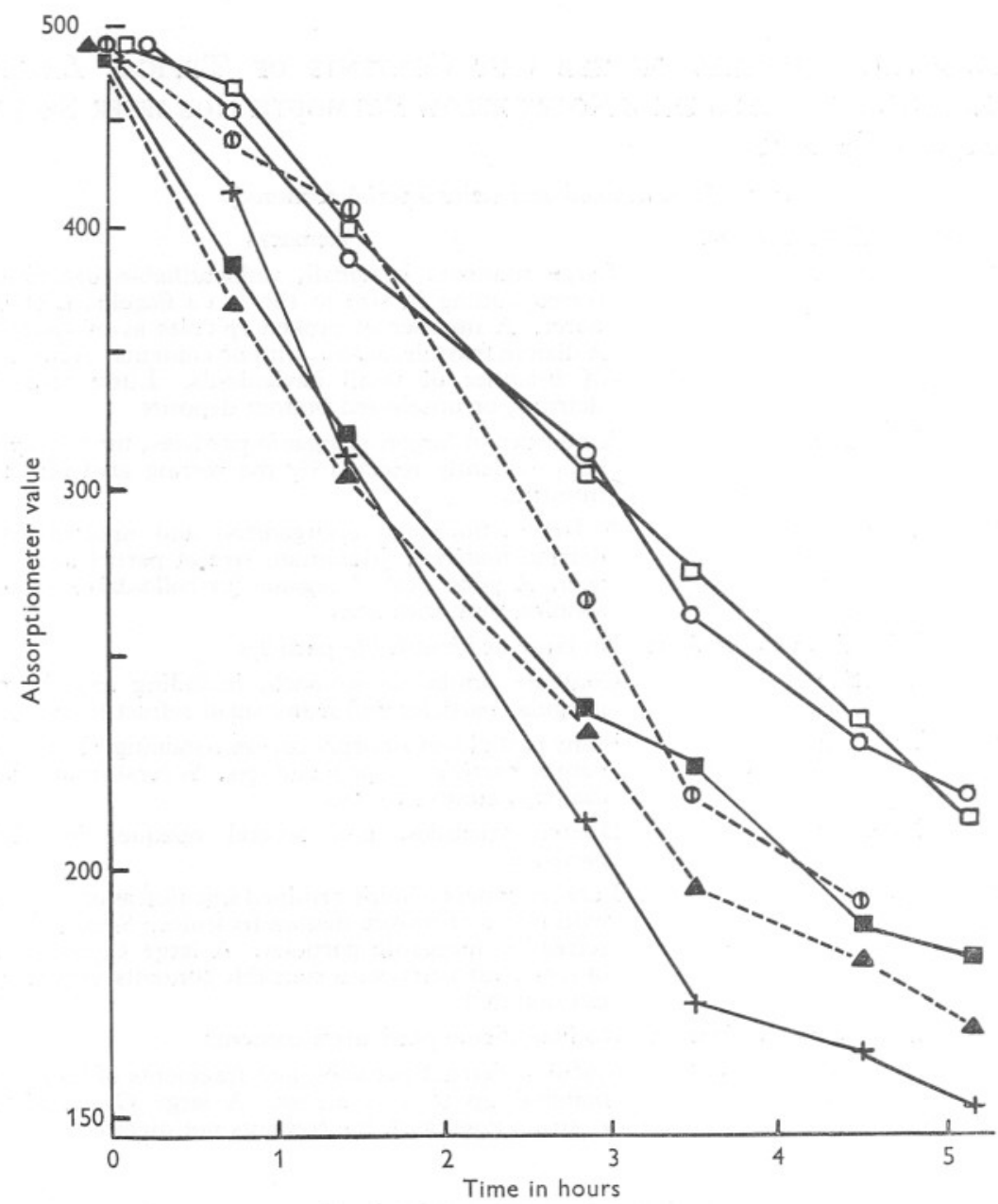

Fig. II. Filtering rates in Phaeodactylum of three series, each of to large Lasaea rubra, from near low-water mark (location $\mathbf{r}$ ), and from the upper limit of the range (location $5^{-6}$ ), at Wembury. $\square-\square, \bigcirc-\bigcirc$ and $\Phi--\Phi$ are from the lower level, and +-+ , - D and $\mathbf{\Delta}-\boldsymbol{\Delta}$ from the upper level. The filtering rate in the high tidal series is initially greater, becoming reduced to that of the upper series after $c .3^{\frac{1}{2}} \mathrm{~h}$. Of the lowtidal series, $(1--\Phi$ exhibited a higher filtering rate than the remaining two, reaching the same performance as the high tidal series after $\mathrm{I}_{2} \frac{1}{\mathrm{~h}}$. 
submersion. The largest size $(3.0 \mathrm{~mm})$ is reached at the lower tidal positions (Morton's locations I and 2); and the smallest adult shells (never more than $2 \mathrm{~mm}$ in length) are found in tufts of Pygmaea, much higher on the shore (location 8). The latter habitat seems to be the most harsh which this species has to tolerate. The percentage exposure between tides may exceed 80 , and at Wembury, the areas of Pygmaea on sun-exposed rock faces become desiccated and brittle between tides during summer. The shells of Lasaea become entirely dry. Yet in spite of the apparent difficulties of the habitat, the Pygmaea tufts are-as was pointed out by Colman (1940)- the most certain places to collect Lasaea rubra in large numbers alive.

In some places there appear to be exceptions to the rule of greater size with longer submersion. One example is shown by the Lasaea at Blackstone Rocks, Wembury, at the extreme upper limit of the Chthamalus zone, at Morton's locations 5 and 6 (percentage exposure $c .90$ ). The shells here are large in modal and maximum size. Their size induced us to do some experiments on their filtering rates as compared with those of animals of comparable size selected from lower tidal levels (percentage exposure 45). The results appeared interesting, in showing a marked initial increase in the filtering rate of those higher on the shore as compared with those lower down (see Fig. II).

The ability to filter rapidly continued for a longer period than the normal time of submersion or contact with splash, which could never much exceed $2 \mathrm{~h}$. Apparently Lasaea rubra living at this high level may be equipped to take rapid advantage by fast filtering of the presence of even the most temporary patches of water lodged by the splash.

The results of these preliminary experiments do no more than to point a field which it is hoped in the future to explore: the study of upper tidal Lasaea rubra as a filter-feeding animal living under hard conditions. It would be interesting to find whether Lasaea is regularly able to compensate for an unfavourable position on the shore by an increased filtering rate. In future experiments it is hoped to investigate possible differences in growth rate, metabolic rate and filtering rate, correlated with differences in shore level.

\section{SUMMARY}

The rates of filtering, feeding and digestion have been experimentally investigated in the small intertidal lamellibranch Lasaea rubra. Absorptiometric determinations of filtering rates with cultures of Phaeodactylum tricornutum were carried out over $3 \mathrm{~h}$ periods. The filtering rate is strongly affected by temperature change, but not-it appears-by variations in the turbidity of the culture. For a group of 20 animals, the filtering rate reached an upper level of more than I ml. per hour. A very comparable order of value has been previously established for other lamellibranchs studied. 
Variations in filtering rate were investigated with the use of unialgal cultures of other organisms. The toxic Gymnodinium veneficum was not filtered at all. G. vitiligo, Chlorella stigmatophora, Nannochloris atomus, Peridinium trochoideum and Dicrateria inornata were filtered at rates lower than for Phaeodactylum; Exuviaella baltica, Prorocentrum micans, Isochrysis galbana and Chromulina pusilla were filtered at higher rates. The cell size of the organismlike the density of the culture-had no detectable effect on filtering rate. Samples of Lasaea pre-treated with the toxic Gymnodinium veneficum showed a subsequent depression of the normal filtering rate with Phaeodactylum. Eventual recovery was obtained.

Haemacytometric counts of stomach contents were made after feeding with Phaeodactylum and the rate of digestion established over a $2 \mathrm{~h}$ period. Preliminary digestion, with the reduction of the cell to a 'ghost', takes place extracellularly.

The ability of Lasaea to carry out sorting of mixed suspensions was investigated, after feeding with varied particle sizes, by examination of the remaining supernatant culture, the pseudofaeces and the gut contents. Only with mixtures of Peridinium and Dicrateria and of Phaeodactylum and 'Kieselguhr' does evidence of sorting ability appear.

Lasaea was found to digest Phaeodactylum and Isochrysis rapidly, the diatom Thalassiosira slowly and Peridinium not at all. It is thought likely that organic detritus figures largely in its food budget.

\section{REFERENCES}

AtKINs, D., I936. On the ciliary mechanisms and interrelationships of lamellibranchs. Part I. Some new observations on sorting mechanisms. Quart. F. micr. Sci., Vol. 79, pp. 18I-308.

- 1938. On the ciliary mechanisms and interrelationships of lamellibranchs. Part VII. Latero-frontal cilia of the gill filaments and their phylogenetic value. Quart. F. micr. Sci., Vol. 80, pp. 345-436.

BAINBRIDGE, R., I953. Studies on the interrelationships of zooplankton and phytoplankton. F. Mar. biol. Ass. U.K., Vol. 32, pp. 385-447.

CoE, W. R., I947. Nutrition, growth and sexuality of the Pismo Clam (Tivela stultorum). F. exp. Zool., Vol. 104, pp. I-24.

Colman, J. S., I940. On the faunas inhabiting intertidal seaweeds. F. Mar. biol. Ass. U.K., Vol. 24, pp. 129-183.

Fox, D. L. (ed.), I936. The habitat and food of the California sea mussel. Bull. Scripps Instn Oceanogr. tech., No. 4, pp. I-64.

Fox, D. L. \& CoE, W. R., I943. Biology of the California sea mussel (Mytilus californianus). II. Nutrition, metabolism, growth and calcium deposition. F. exp. Zool., Vol. 93, pp. 205-249.

Fox, D. L., SverdRup, H. U. \& CUNNINGHAM, J. P., 1937. The rate of water propulsion by the California Mussel. Biol. Bull., Woods Hole, Vol. 72, pp. 417-438.

GALTSOFF, P. S., 1928. Experimental study of the function of the oyster gills and its bearing on the problems of oyster culture and sanitary control of the oyster industry. Bull. U.S. Bur. Fish., Vol. 44, pp. I-39. 
Galtsoff, P. S., Chipman, W. A., Engle, J. B. \& Calderwood, H. N., I947. Ecological and physiological studies of the effect of sulfate pulp mill wastes on oysters in the York River, Virginia. Fish. Bull., U.S., Vol. 43, No. 5I, pp. 59-I86.

GlynNe-Williams, J. \& Hobart, J., I952. Studies on the crevice fauna of a selected shore in Anglesey. Proc. zool. Soc. Lond., Vol. I22, pp. 797-824.

Gray, J., I928. Ciliary Movement. Cambridge.

HARVEY, H. W., I948. The estimation of phosphate and total phosphorus in sea-waters. F. Mar. biol. Ass. U.K., Vol. 27, pp. 337-59.

Hendey, N. I., 1954. Notes on the Plymouth 'Nitzschia' culture. F. Mar. biol. Ass. U.K., Vol. 33, pp. 335-9.

Jensen, P. B., I915. Studies concerning the organic matter of the sea bottom. Rep. Danish biol. Sta., Vol. 22 (I9I4), pp. I-39.

JørGENSEN, C. B., I949. The rate of feeding by Mytilus in different kinds of suspension. F. Mar. biol. Ass. U.K., Vol. 28, pp. 333-44.

Jørgensen, C. B. \& Goldberg, E. D., I953. Particle filtration in some ascidians and lamellibranchs. Biol. Bull., Woods Hole, Vol. I05, pp. 477-89.

Loosanoff, V. L., I949. On the food selectivity of oysters. Science, Vol. Iro, p. I22.

LOOSANOFF, V. L. \& ENGLE, J. B., I947. Effect of different concentrations of microorganisms on the feeding of oysters (O. virginica). Fish. Bull., U.S., Vol. 42, No. 5I, pp. 3I-57.

LOOSANOFF, V. L. \& NoMEJKo, C. A., I946. Feeding of oysters in relation to tidal stages and to periods of light and darkness. Biol. Bull., Woods Hole, Vol. 90, pp. 244-64.

MacGinitie, G. E., I94I. On the method of feeding of four pelecypods. Biol. Bull., Woods Hole, Vol. 80, pp. I8-25.

Morton, J. E., I954. The crevice faunas of the upper intertidal zone at Wembury. F. Mar. biol. Ass. U.K., Vol. 33, pp. 187-224.

Newell, B. S., I953. Cellulolytic activity in the lamellibranch crystalline style. 7. Mar. biol. Ass. U.K., Vol. 32, pp. 49I-5.

OldFIELD, E., I955. Observations on the Anatomy and Mode of Life of Lasaea rubra (Montagu) and Turtonia minuta (Fabricius). Proc. malacol. Soc. Lond., Vol. 3I, pp. 226-49.

ORTON, J. H., I9I4. On ciliary mechanisms in brachiopods and some polychaetes, with a comparison of the ciliary mechanisms on the gills of molluscs, Protochordata, brachiopods and cryptocephalous polychaetes, and an account of the endostyle of Crepidula and its allies. F. Mar. biol. Ass. U.K., Vol. Io, pp. 283-3I I.

PINTO, J. DOS S., I953. Intoxições alimentares e outros acidentes causãdos par flagelados marinhos. Rev. Med. contemp., Madr., Vol. 71, pp. I03-I9.

Popham, M. L., I940. The mantle cavity of some of the Erycinidae, Montacutidae and Galeommatidae, with special reference to the ciliary mechanisms. F. Mar. biol. Ass. U.K., Vol. 24, pp. 549-87.

SPENCER, C. P., I954. Studies on the culture of a marine diatom. F. Mar. biol. Ass. U.K., Vol. 33, pp. 265-90.

Steedman, H. F., I950. Alcian Blue 8GS : a new stain for mucin. Quart. F. micr. Sci., Vol. 9I, pp. 477-9.

Stephenson, M., I939. Bacterial Metabolism. London.

TAmmes, P. M. L. \& Dral, A. D. G., I955. Observations on the straining of suspensions by Mytilus. Arch. néerl. Zool., Vol. II, pp. 87-II2.

VERWEY, J., I952. On the ecology of distribution of cockle and mussel in the Dutch Waddensea, their role in sedimentation and the source of their food supply, with a short review of the feeding behaviour of bivalve mollusks. Arch. néerl. Zool., Vol. IO, pp. I7I-239. 
Willemsen, J., I952. Quantities of water pumped by mussels (Mytilus edulis) and cockles (Cardium edule). Arch. néerl. Zool., Vol. 10, pp. 153-60.

WILson, D. P., 1946. The triradiate and other forms of Nitzschia closterium (Ehrenberg) Wm. Smith forma minutissima of Allen and Nelson. F. Mar. biol. Ass. U.K., Vol. 26, pp. 235-70.

YoNGE, C. M., I926. Structure and physiology of the organs of feeding and digestion in Ostrea edulis. F. Mar. biol. Ass. U.K., Vol. I4, pp. 295-386.

- 1938. Evolution of ciliary feeding in the Prosobranchia, with an account of the feeding in Capulus ungaricus. F. Mar. biol. Ass. U.K., Vol. 22, pp. 453-68.

1949. On the structure and adaptations of the Tellinacea: deposit-feeding Eulamellibranchia. Phil. Trans., B, Vol. 234, pp. 29-76. 